Dominika Lewandowska

\title{
PRODIGIUM, PORTENTUM, OSTENTUM, MONSTRUM: IN SEARCH OF MEANING BETWEEN PRACTICE AND DEFINITON*
}

CARL Thulin in an article from 1904 'Synonyma quaedam Latina (Prodigium, portentum, ostentum, monstrum) ${ }^{1}$ aptly summarised the efforts of ancient Grammarians and modern researchers in their attempts to establish the exact meaning of the following terms: 'In verbis prodigium portentum ostentum monstrum inter se distinguendis et grammatici antiqui et viri docti posteriores multum frustra laboraverunt'. ${ }^{2}$ Thulin pointed out that these expressions are not only synonymous, but even within a single author's work they appear in various guises and contexts ('Nullae enim normae universales statui possunt ${ }^{3}$ ). Attempts to derive meaning from Indo-European

\footnotetext{
Scientific paper financed by the Ministry of Science and Higher Education of Poland from the research budget for 2017-2021 as a research project under the 'Diamond Grant' programme (6th edition); project number: DI2016000646; title: 'The Character of the 'Traditional' Roman Religion in the Empire Period (End of 1st Century BCE - 6th Century CE) - Analysis of Institutional and Terminological Changes.'

${ }^{1}$ C. Thulin, 'Synonyma quaedam Latina (Prodigium, portentum, ostentum, monstrum)', [in:] Commentationes philologae in honorem Iohannis Paulson, Gothenburg 1905, pp. 194-213.

${ }^{2}$ Ibidem, p. 194

${ }^{3}$ Ibidem, p. 201.
} 
etymologies and an overview of the state of research also proved to be insufficient for solving this problem, and perhaps the greatest manifestation of Thulin's 'frustration' was not so much the sentence beginning his dissertation, but rather the absence of any definitive conclusion.

'Viri docti posteriores' did not end with Thulin. Successive generations of researchers took up the mantle, ${ }^{4}$ working on the ancient definitions of these four terms. I intend to approach this issue from another side. While I fully agree with the statement that the four terms are synonymous, ${ }^{5}$

\footnotetext{
${ }^{4}$ Select bibliography: F. B. Krauss, An Interpretation of the Omens, Portents, and Prodigies Recorded by Livy, Tacitus, and Suetonius, Philadelphia 1930, pp. 31-34; P. Händel, s.v. 'prodigium', [in:] K. ZIEGLER (ed.), Realencyclopädie der Classischen Altertumswissenschaft, vol. 23.2 (Psamathe bis Pyramiden), Stuttgart 1959, pp. 2283-2296; R. BLoch, Les Prodiges dans l'antiquité classique, Paris 1963, pp. 84-86; A. SzANTyr, s.v. 'monstrum', [in:] Thesaurus Linguae Latinae, vol. 8.10 [Bibliotheca Scriptorum Graecorum et Romanorum Teubneriana], Leipzig 1964, pp. 1446-1454; É. Benveniste, Dictionary of Indo-European Concepts and Society, transl. G. Agamben, Chicago 2016 [Paris 1969], pp. 517-524; H. Remus, 'Does terminology distinguish early Christian from pagan miracles?', Journal of Biblical Literature 101/4 (1982), pp. 535-537; D. DAlla, 'Status e rilevanza dell' ostentum', [in:] V. Giuffrè (ed.), Sodalitas. Scritti in onore di Antonio Guarino, vol. 2, Naples 1984, pp. 519-532; J. CÉARD, La nature et les prodiges : L'insolite au XVI siècle, Geneva 1996, pp. 39-40; C. Moussy, 'Signa et portenta', [in:] L. SAwicki, D. Shalev (eds.), Donum Grammaticum, Louvain 2002, pp. 265-275; D. ENGELS, Das römische Vorzeichenwesen (753-27 v. Chr.), Stuttgart 2007, pp. 264-282; A. CRIVĂŢ, 'El léxico de lo extraordinario en las Etimologías de Isidoro de Sevilla (portenta, ostenta, prodigia, monstra)', Revue roumaine de linguistique 56/3 (2011), pp. 257-276; A. A. MonTERreAL, 'Precisiones terminológicas sobre ostentum D.50,16,38 (Ulpianus libro 25 ad Edictum)', [in:] P. Resina Sola (ed.), Fundamenta Iuris. Terminología, Principios e Interpretatio, Almeria 2012, pp. 49-64; K. BEERDEN, Worlds Full of Signs: Ancient Greek Divination in Context [= Religions in the Graeco-Roman World 176], Leiden - Boston 2013, pp. 108-110; C. Pelloso, 'Sew it up in the sack and megre it into running waters!', [in:] D. CAPRI (ed.), Monsters and Monstrosity: From the Canon to the Anti-Canon: Literary and Furidical Subversions, Berlin - Boston 2019, pp. 63-70; I. KACZOR, 'The sacred and the poetic: The use of religious terminology in Ovid's words', Symbolae Philologorum Posnaniensium Graecae et Latinae 29/2 (2019), pp. 17-35.

${ }^{5}$ OLD [= Oxford Latin Dictionary], s.v. 'prodigium': '1. An unnatural event or manifestation portending a disaster, etc., prodigy; 2. A monstrous event or situation, marvel'; OLD, s.v. 'portentum': '1. An abnormal phenomenon, usu. regarded as foreshadowing some momentous event, a portent; 2. (without ref. to future) Something unnatural or extraordinary, a prodigy; (esp.) a strange or abnormal creature, monster; also an abnormal growth, monstrosity; (applied to persons) a monster of wickedness, vice, or sim.; 3. Something perversely imagined or devised, an extravagant or monstrous practice, act, invention, etc.; a fantastic or supernat-
} 
I would like to assess with what frequency and in what context the ancient Latin authors used them; and then I propose to look at the definitions of ancient grammars from the point of view of how they themselves tried to solve the issue of synonymity of important terms from their mother tongue. It is not my point to propose an authorial definition for prodigium, portentum, ostentum, and monstrum, but to see how the ancient people themselves used these terms (emic approach); and how adequate the definitions of the Antiquarians and Grammarians were.

\section{FREQUENCY OF USE OF PRODIGIUM, PORTENTUM, OSTENTUM, AND MONSTRUM}

I decided to start my investigation by examining how often the Latin authors used the words prodigium, portentum, ostentum, and monstrum, making the following assumptions. The most reliable result would be to collect all the Latin ancient sources (closed dataset) and examine each of the above-mentioned words in this set. However, it is problematic to arbitrarily determine the chronological framework of the analyzed sources. The latest of the authors I considered are: Gregory of Tours, Isidore of Seville, and Paul the Deacon, but I only took into account those of their works that I considered to be the most dependent, in terms of content and form, on the legacy of the Ancients. Among the earliest authors considered here were Varro and Sallustius. Apart from special cases, I did not distinguish authors whose works are preserved in fragments; however, if one of the examined words was included in the quotations preserved by later commentators, it is noted in the table, in the category 'Grammatical'. The final result is a dataset of 1,489 words. I took into account only nouns, omitting their derivate verb forms, adjectives and adverbs.

ural story, conceit, or sim.'; $O L D$, s.v. 'ostentum': 'A manifestation or occurrence foreshadowing future events, a portent, prodigy; (in wider sense) a wonder, marvel'; OLD, s.v. 'monstrum': '1. An unnatural thing or event regarded as an omen, a portent, prodigy, sign; 2. An awful or monstrous thing, event, etc.; 3. A monstrous or horrible creature, monstrosity, monster'. 
I divided the table into source categories, which I considered to be the best method for ordering the preserved material. However, it must be pointed out at the outset that some of the works fall between two or more categories. In such cases, I had to make a decision based on my estimation of which features should be foregrounded. In the category 'Historiography' I included classical historical narratives, breviaries, chronicles and the emperors' biographies. ${ }^{6}$ Obsequens was also included in this list, because his work, although it is a collection of prodigies and not a historical work, is based on Livy (or some author dependant on Livy) and echoes Livian terminology. In the category 'Poetry' I placed Republican, Imperial and Late Ancient poets, ending with Dracontius. In the 'Drama' category there are placed the stage works (tragedies and comedies) of four authors. I included only those authors whose works have been preserved in whole or in significant part. In the 'Prose' category there are the non-poetic works of a purely literary character, which, in my opinion, did not fit into other areas. I consider this category to be the least satisfactory, but sufficient for my purposes. The 'Philosophy \& Rhetoric' category is the least homogeneous, because we find non-poetic philosophical works only in the corpus of Cicero's writings. I also found that even the philosophical ones in terms of content, are highly rhetorical in form, and thus create too many points of contention when trying to make this category separate. I also included letters, treating them as a specific kind of rhetoric. I believe that this is particularly justified in the case of Cicero, since he used the terminology in question in the same way in both speeches and letters (although some people may argue that it is necessary to create a category called 'Epistolography'; I myself only rejected this idea after a thorough review of the material). In the category 'Technical' I included works and treatises discussing some area of knowledge (natural history, paradoxography, agronomy, etc.). In the category 'Grammatical' I placed works devoted to language, lexicons, and grammat-

\footnotetext{
${ }^{6}$ There are different views on what genres should be included in the 'Historiography' category. For a detailed discussion and further bibliography, see L. van Hoof, P. van Nuffelen, The Fragmentary Latin Histories of Late Antiquity (AD 300-620): Edition, Translation and Commentary, Cambridge 2020, pp. 7-13, and L. van Hoof, P. van Nuffelen (eds.), Clavis historicorum antiquitatis posterioris: An Inventory of Late Antique Historiography (A.D. 300-800) [= Corpus Christianorum, claves - subsidia 5], Turnhout 2020, pp. XVI-LXX.
} 
ical commentaries. The category 'Legal' includes only Codex Iustiniani and Digesta, in which a total of only four testimonials of the words tested appear, but these are important examples. The last category, 'Early Christian', contains my selection of Christian authors who commented on the Pagan world from a Christian perspective, and thus also referred to the phenomena described by the terms examined in this paper. This selection of Christian authors serves a comparative purpose and is by no means a comprehensive study of how Christianity adapted Pagan vocabulary.

I also took into consideration the context in which the words under discussion occurred, separating them into 'divinatory' and 'various' ('various', in fact, most often turned out to be a metaphorical or rhetorical). In doubtful contexts, I favor the 'divinatory' interpretation. However, I intentionally use the term 'divinatory context' and not simply 'sign from the gods'; but I will justify this further on. I have also assigned the definitions of Grammarians to the 'divinatory context', since the oldest definition of this kind explained the etymology of each of the terms in question precisely in relation to their 'divinatory' character.

The assignment is based on my interpretation; and certainly another researcher would use a slightly different distribution of this data, but I think the differences would not be significant enough to affect the overall conclusions. I have endeavoured to work out a golden mean between the idea of creating as complete a set of data as possible and a reasonable exclusion of some authors and genres (this mainly concerns Christian authors and whole genres like hagiography). The construction of a dataset could, of course, also have been hindered by my accidental omissions. Nevertheless, at the end of this paper, I annex a list containing sigla of all the words placed in the table, hence my proposal of material distribution is verifiable and modifiable. Thus, I adjudge the sample of almost 1,500 words to be sufficiently representative for the Latin sources of the ancient period. 


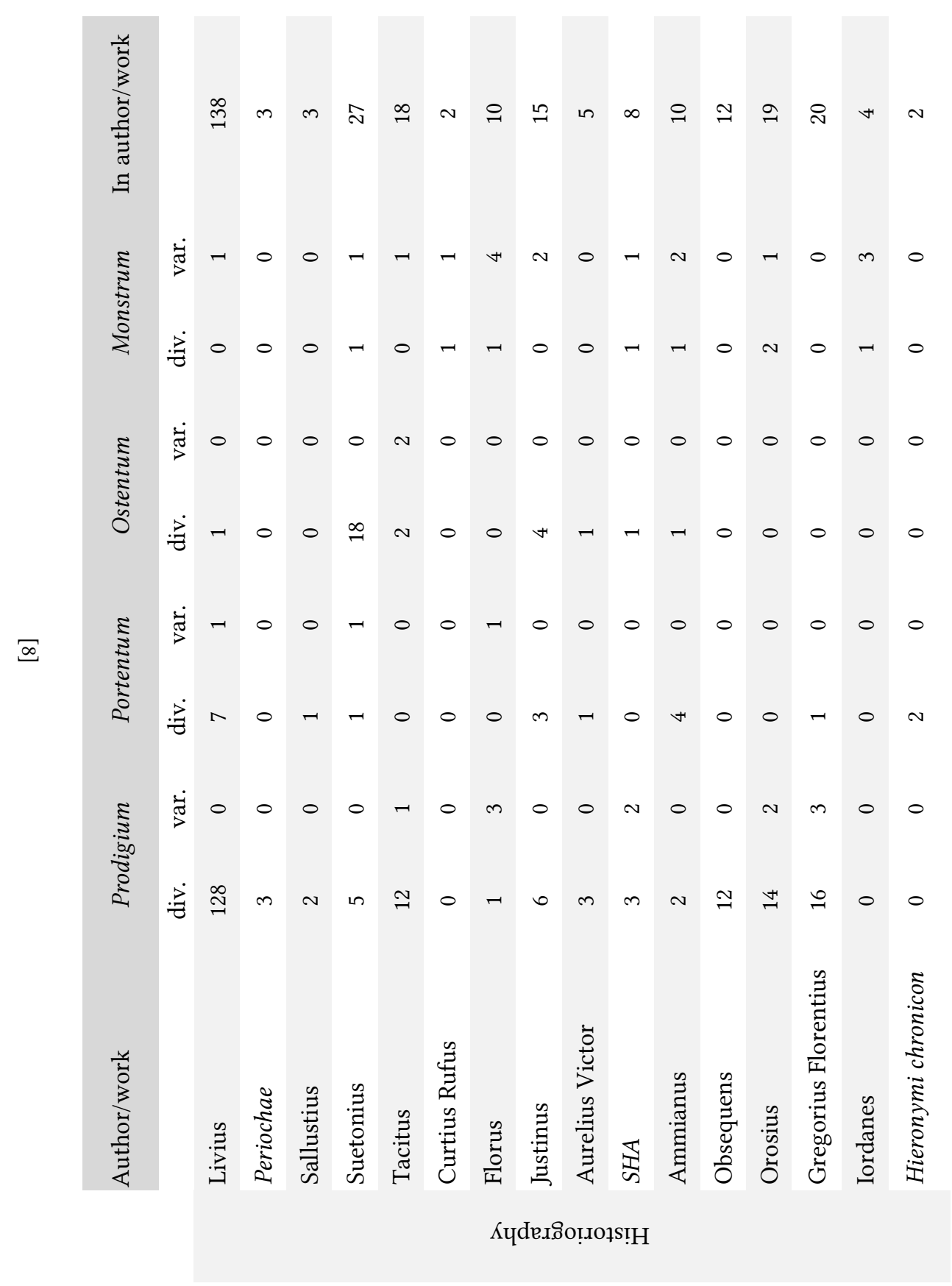




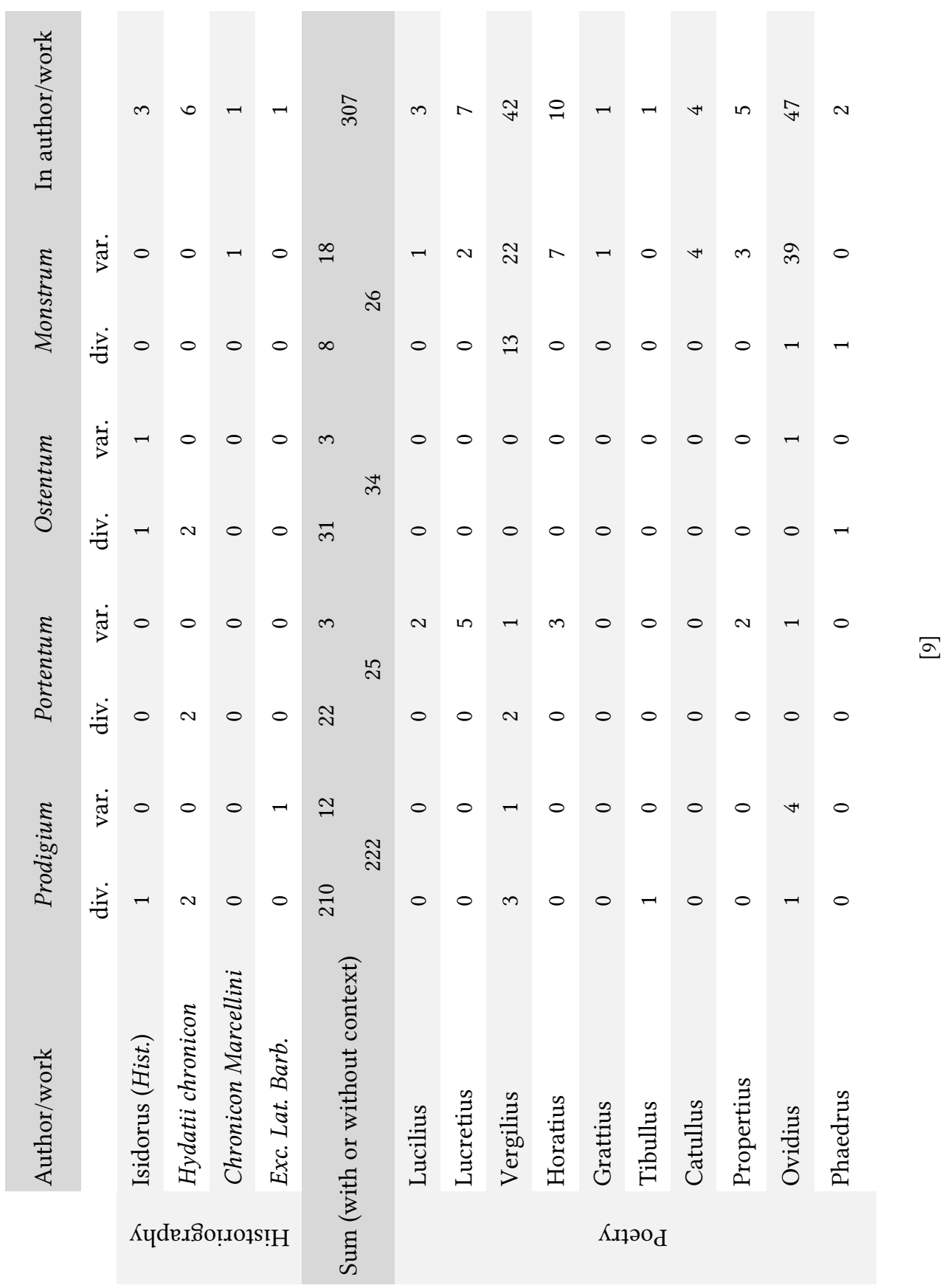




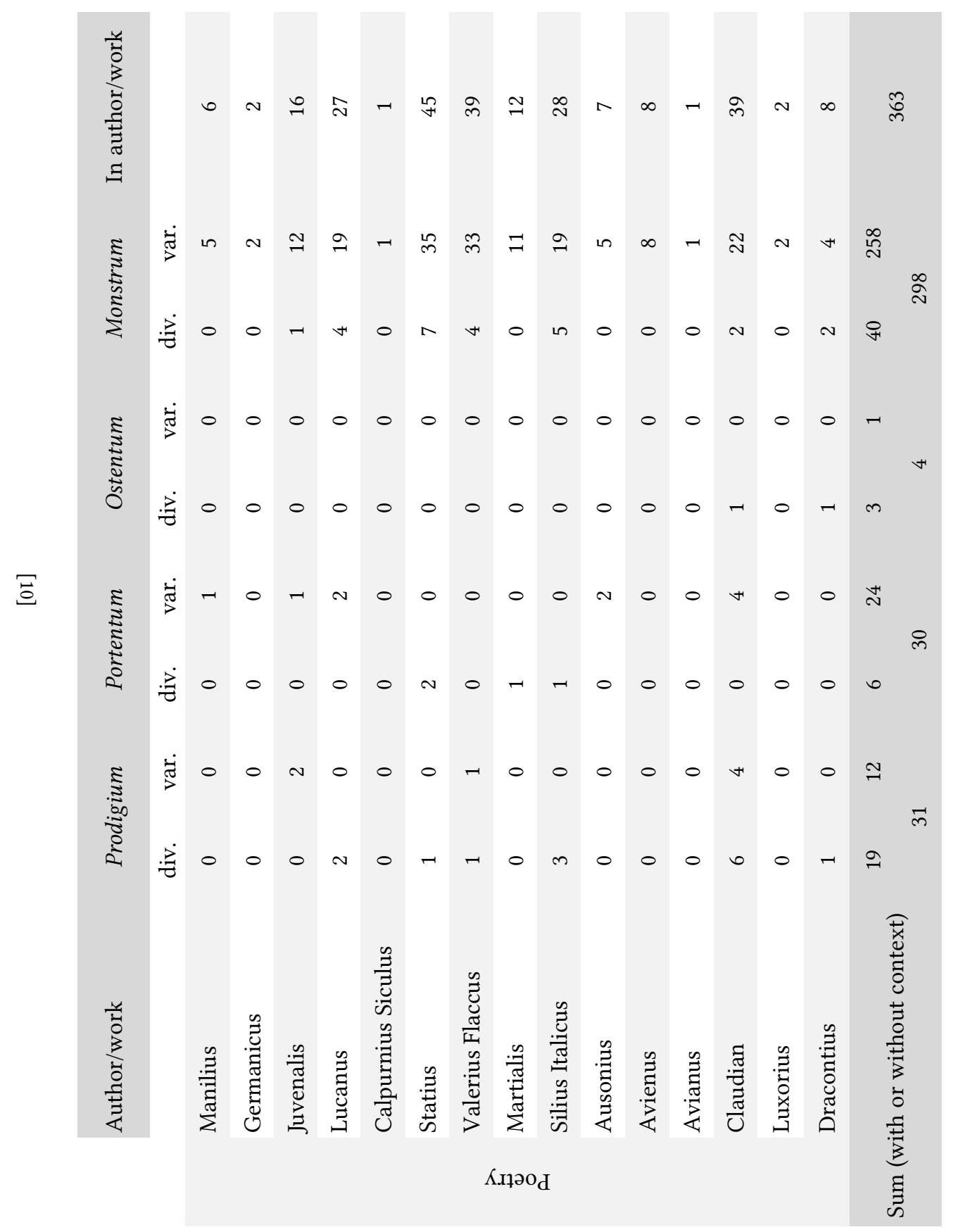




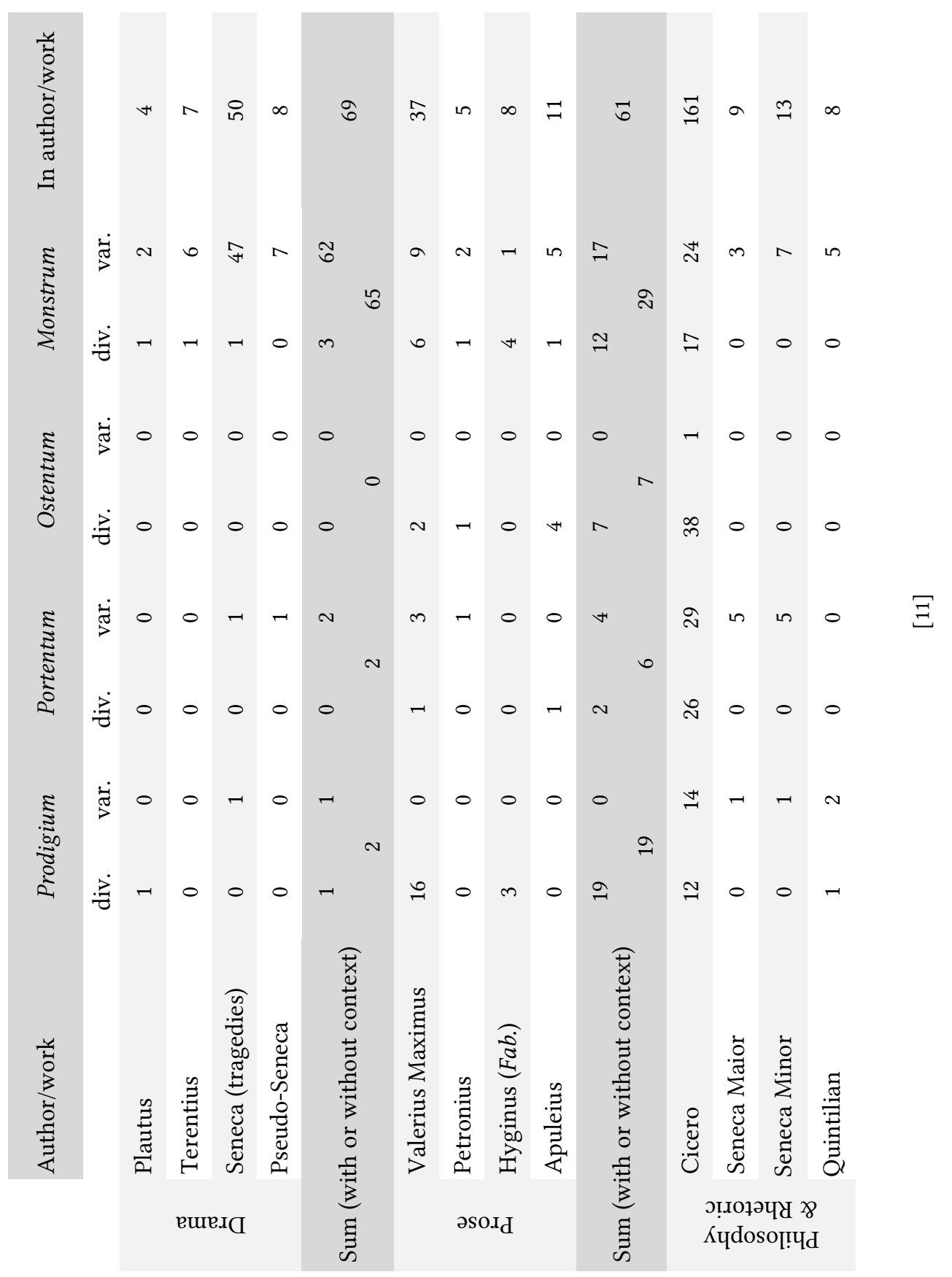




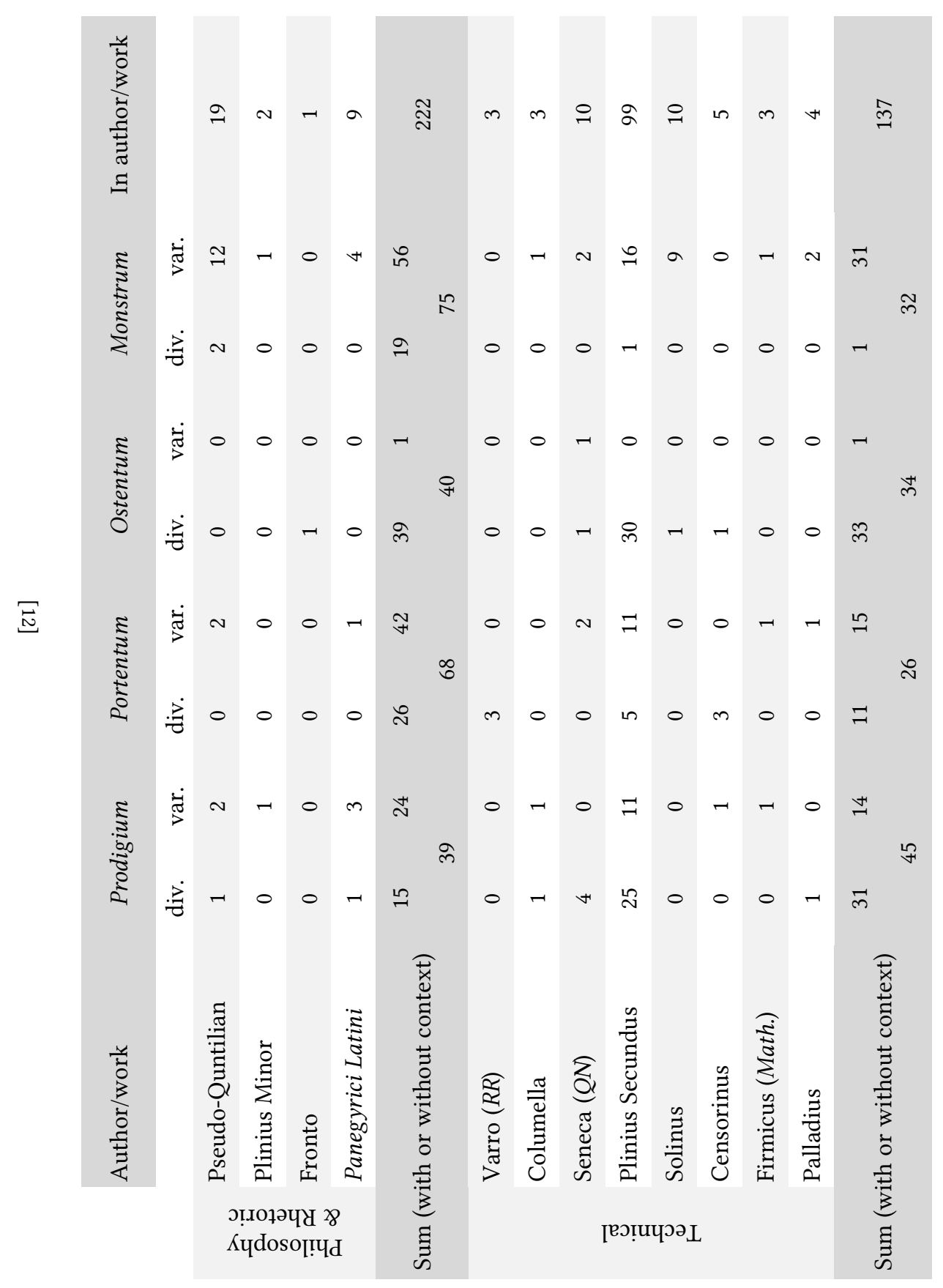




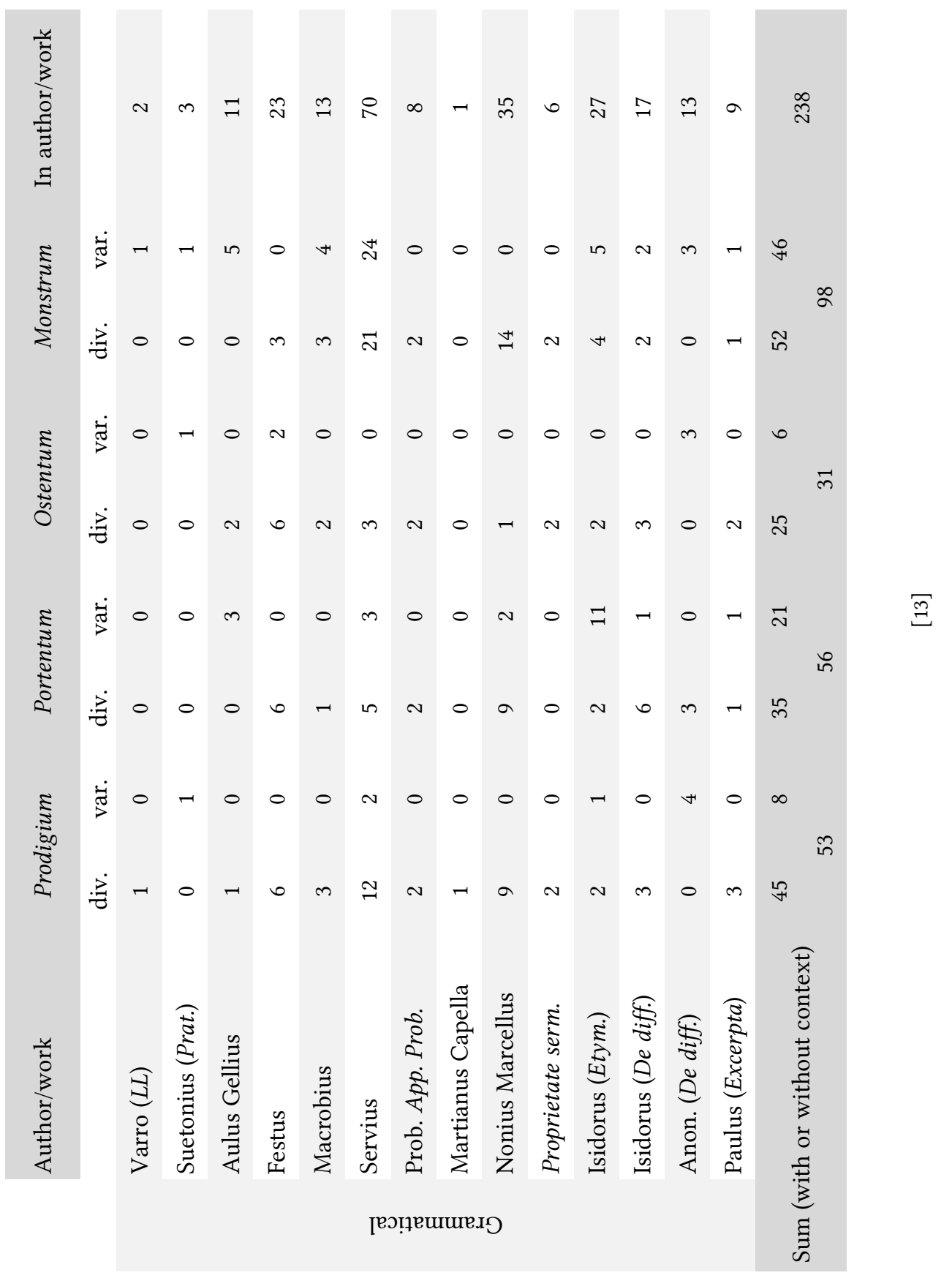




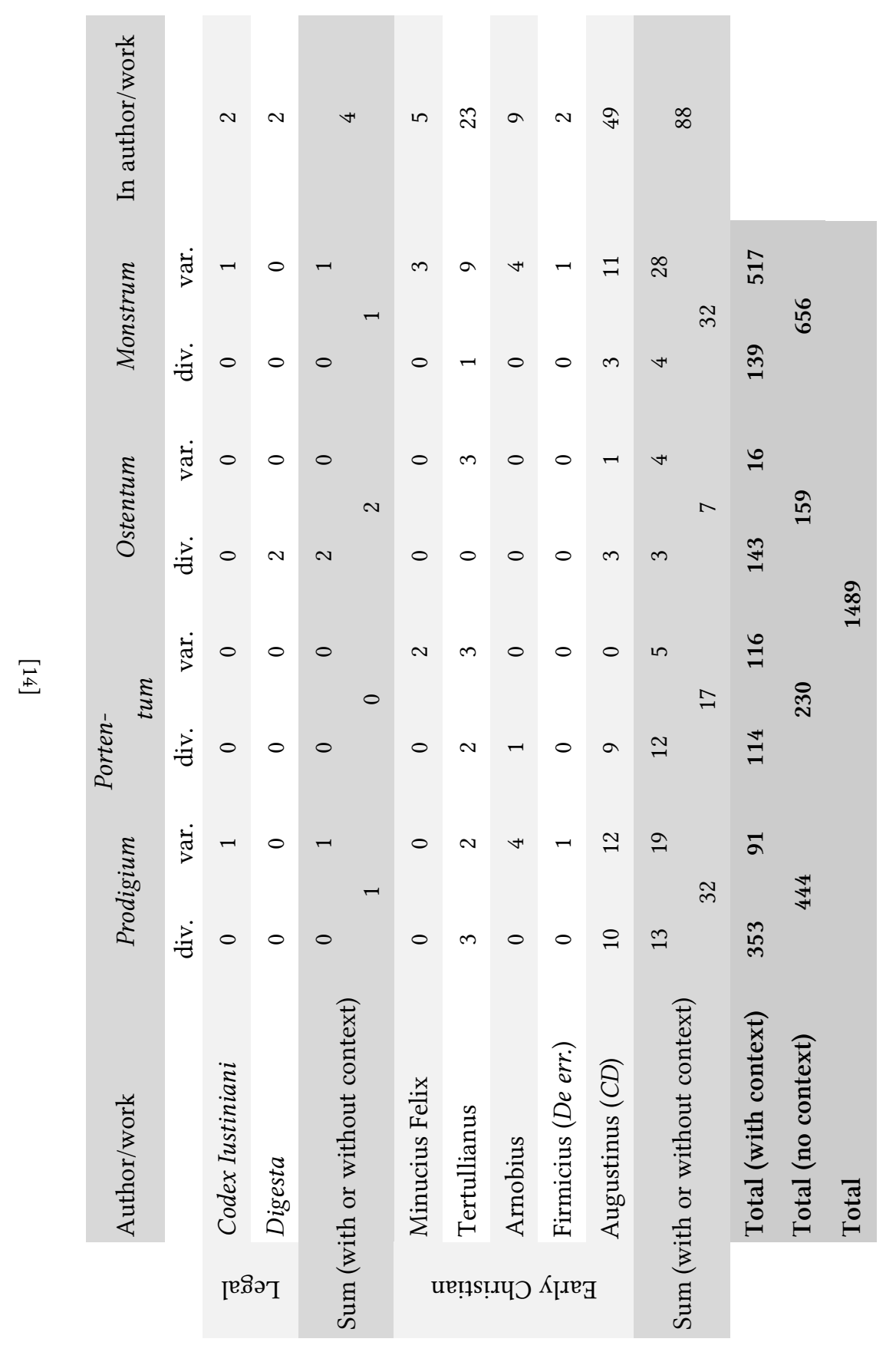




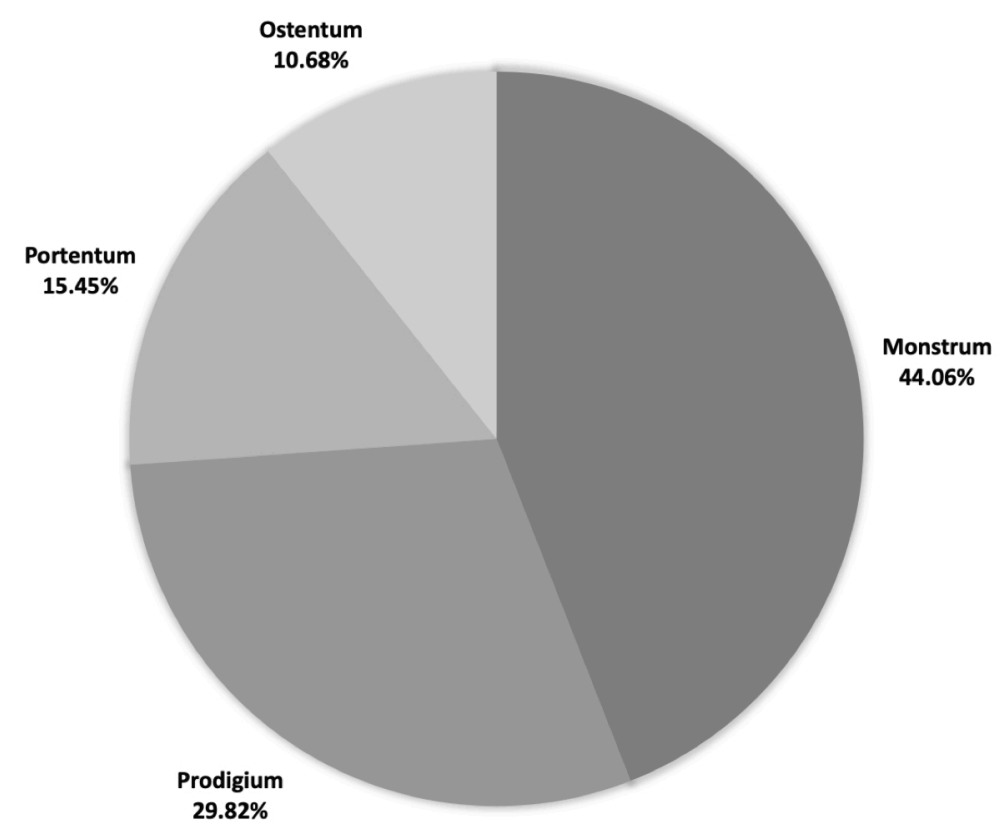

Fig. 1. The percentage share of each of the examined words in the dataset

The table demonstrates that each of the examined words actually occurred in a 'divinatory' context and these were not isolated cases (this means, they are not, for example, an anomaly due to the style of a single author, but indicate a general usage of these terms), so initially we can say that they are synonymous. Of the four words examined, monstrum occurs most frequently in sources (44.06\%), followed by prodigium (29.82\%), then portentum (15.45\%), and ostentum (10.68\%).

However, it must be taken into account that only half $(50.3 \%, 749$ examples) of all the attestations are in a 'divinatory' context. If we use only the 'divinatory' context for the calculations, prodigium turns out to be the most common choice of the Latin authors (47.13\%), followed by ostentum (19.1\%) and monstrum (18.56\%), and portentum (15.22\%). 


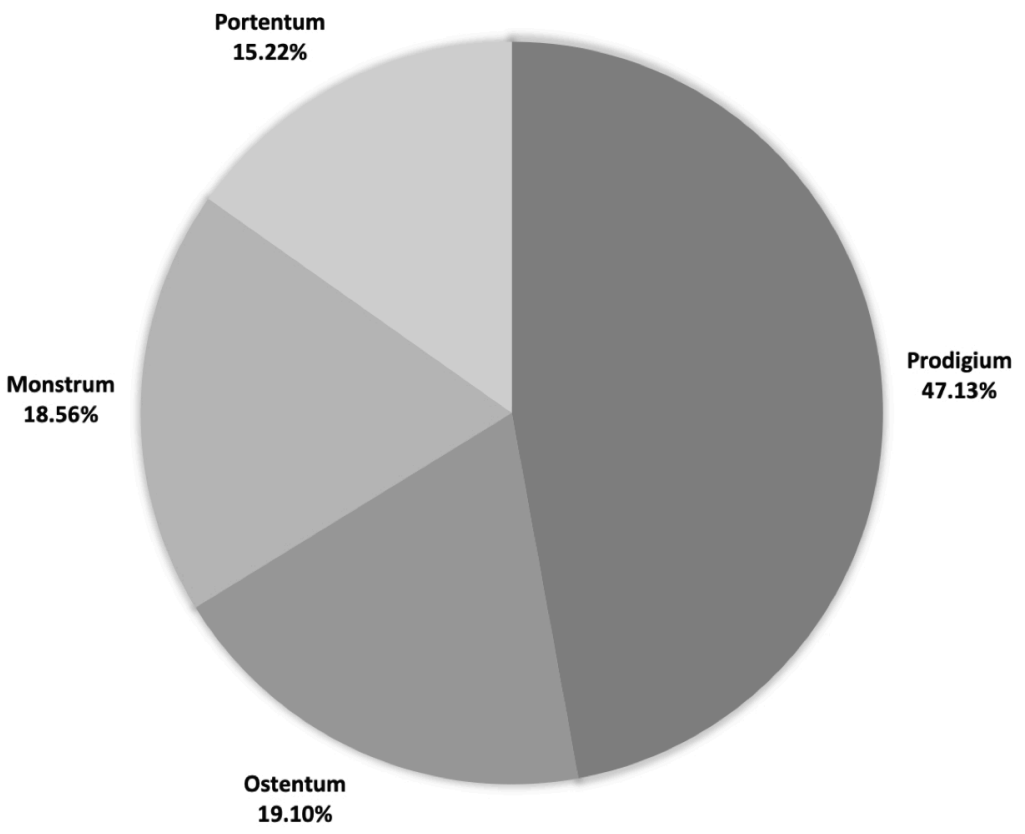

Fig. 2. The percentage share of each of the examined words in the dataset in the 'divinatory' context

As far as source categories are concerned (see fig. 3), the terminology in question is most often used in 'Poetry' (24.38\%) and 'Historiography' (20.68\%). However, considering only the words appearing in the 'divinatory' context (see fig. 4 ), the authors of historical (36.18\%) and grammatical (20.96\%) works used them most often, and 'Poetry', dominant in the general comparison, occupies only fifth place $(9.08 \%)$.

\subsection{Prodigium}

Prodigium was ranked second in terms of frequency of use by ancient authors: 444 attestations, representing $29.82 \%$ of the occurrences in the dataset (see fig. 1). However, taking into account only the 'divnatory' context, prodigium was used much more often to describe disasters announced 


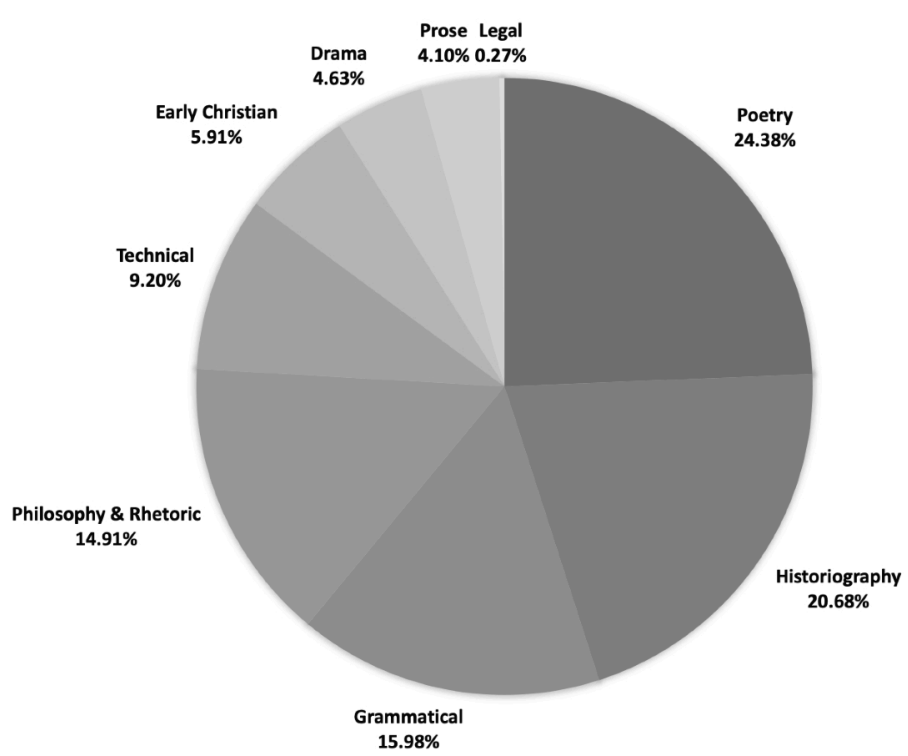

Fig. 3. The percentage share of the words in a dataset in particular source categories

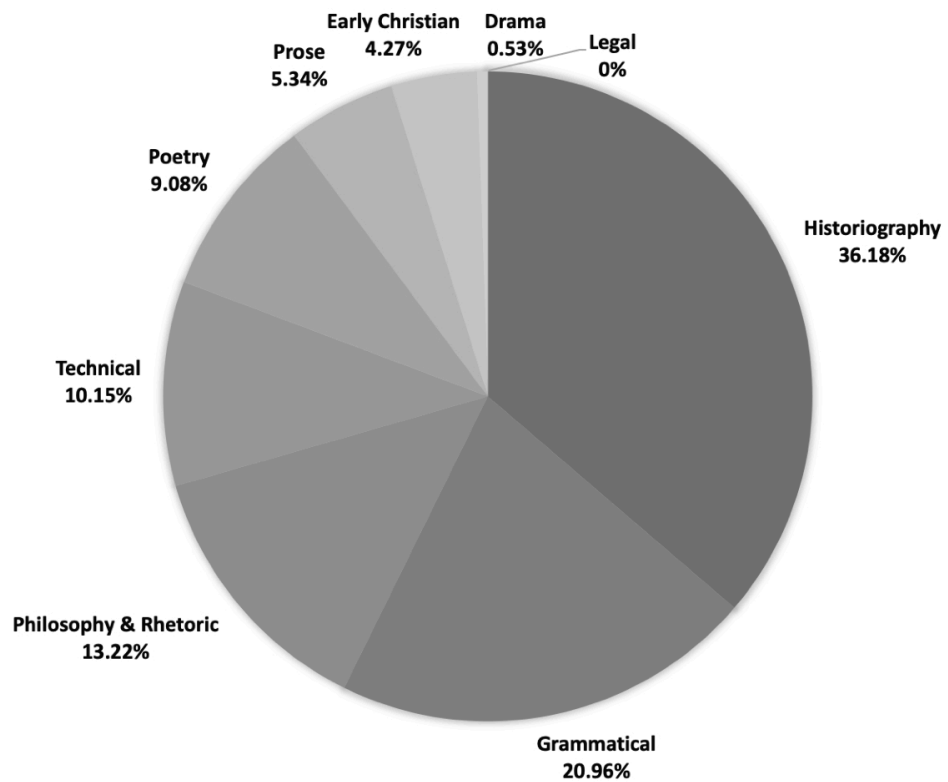

Fig. 4. The percentage share of examined words in the dataset, in particular source categories in the context of 'divinatory' 
by the gods than rival expressions: almost half (47.13\%) of all the 'divinatory' contexts included in the table were described by using prodigium.

The majority of the examples of the word prodigium are found in Livy ( $28.82 \%$ of all attestations in the dataset and $36.26 \%$ of all attestations of the word prodigium in a 'divinatory' context). Periochae and Obsequens' Liber prodigiorum repeat this terminology. It can, of course, be argued that Livy's preferred linguistic usage distorted the results concerning the frequency of use of the word prodigium - on the one hand by having an impact on later Roman historians, who either followed his style (Tacitus), or simply used his work (Valerius Maximus, Orosius, Obsequens), and on the other hand, by 'surviving' in sufficient measure to dominate other historiographic sources.

The Latin historians made recourse to this word a great deal. For example, a faithful adherent of this usage, and therefore included in the table, is Gregory of Tours, with whom we find 16 examined terms, introduced by 'Livian' or 'Tacitian'-like entries as: 'In the seventh year of the reign of king Childebert'. ${ }^{7}$ For the brevists, only Aurelius Victor used the word prodigium, but to a much more limited extent. What is surprising is the SHA case, in which, despite the number of different 'signs' in the text, traditional terminology has actually been abandoned in favour of the omina.

Also in Cicero, we note the distinctive frequency of the use of the word prodigium; although he used this term more often in order to describe political opponents in a blunt way. For Cicero a characteristic manner of building an invective was to multiply the expressions that were associated with the worst possible (Pro Rosc. 38: 'portenti ac prodigii simile'; In Verr. II 2.79: 'monstrum aut prodigium'). ${ }^{8}$ Pliny the Elder often referred to this term, but in his case it should be noted that in Historia naturalis he used the terminology studied here many times and in an inconsistent manner. Nevertheless,

\footnotetext{
${ }^{7}$ Greg. Hist. VI 14: 'Anno igitur septimo Childeberthi regis' (transl. DL). See Gregory of Tours, Libri historiarum X, B. KRusch, W. Levison (eds.) [= Monumenta Germaniae Historica, Scriptores rerum Merovingicarum 1.1], Hanover 1951 (revised edition).

${ }^{8}$ Cicero, Pro Quinctio. Pro Roscio Amerino. Pro Roscio Comoedo. On the Agrarian Law, J. H. Freese (ed. \& transl.) [= The Loeb Classical Library 240], Cambridge MA - London 1930; Cicero, The Verrine Orations, vol. 1: Against Caecilius. Against Verres, Part 1; Part 2, Books 12, L. H. G. Greenwood (ed. \& transl.) [= The Loeb Classical Library 221], Cambridge MA London 1928.
} 


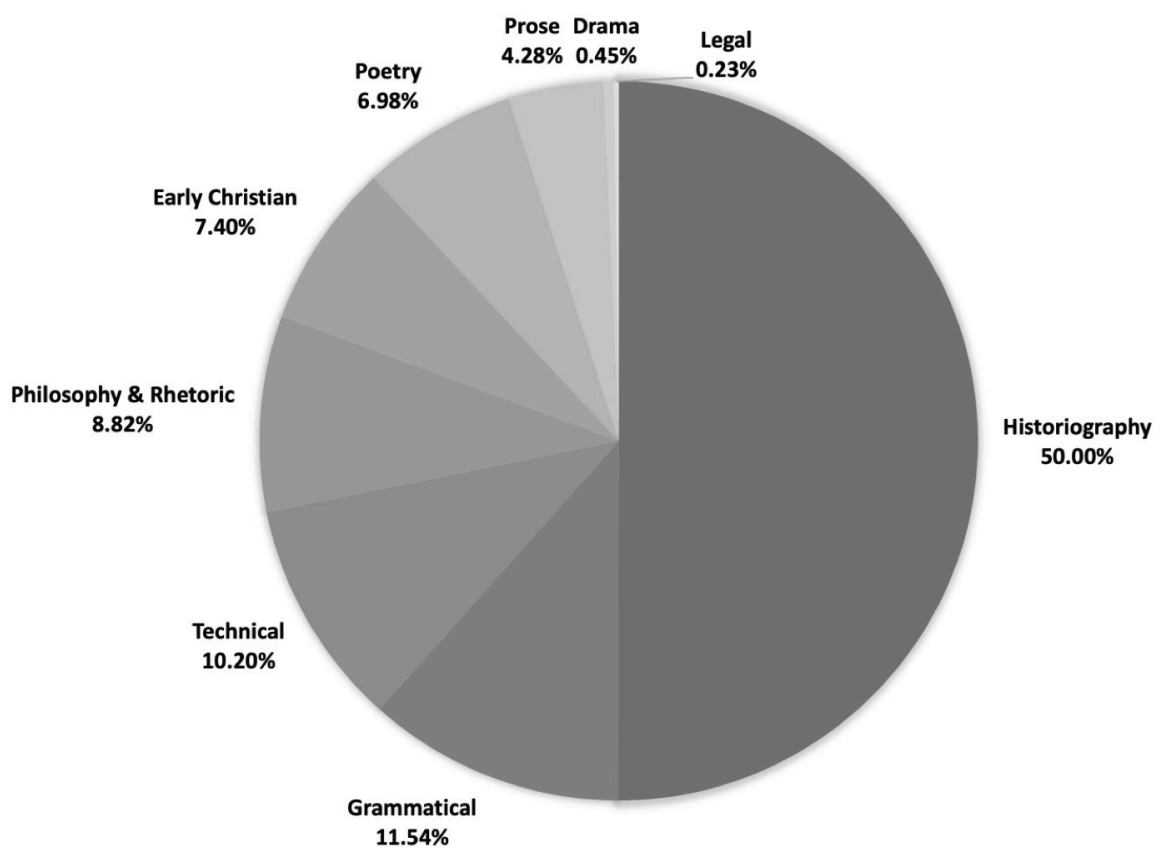

Fig. 5. The percentage of occurrence of the word prodigium in each source category

Pliny most often referred to the word prodigium (among the testimonies from Historia naturalis it is $36.36 \%$, and $25.25 \%$ if only the 'divinatory' context is taken into account). Prodigium can be found many times in the works of the Grammarians, but mainly as an element of etymological definitions. In Augustine's work phenomena called prodigia were used to criticise the traditional Roman religion.

The word prodigium occurs most often in historiographic sources, in the vast majority of cases in a 'divinatory' context. The second group of sources are works of the Grammarians. A significant number of philosophical, rhetorical, and technical sources are provided by Cicero and Pliny the Elder respectively. 


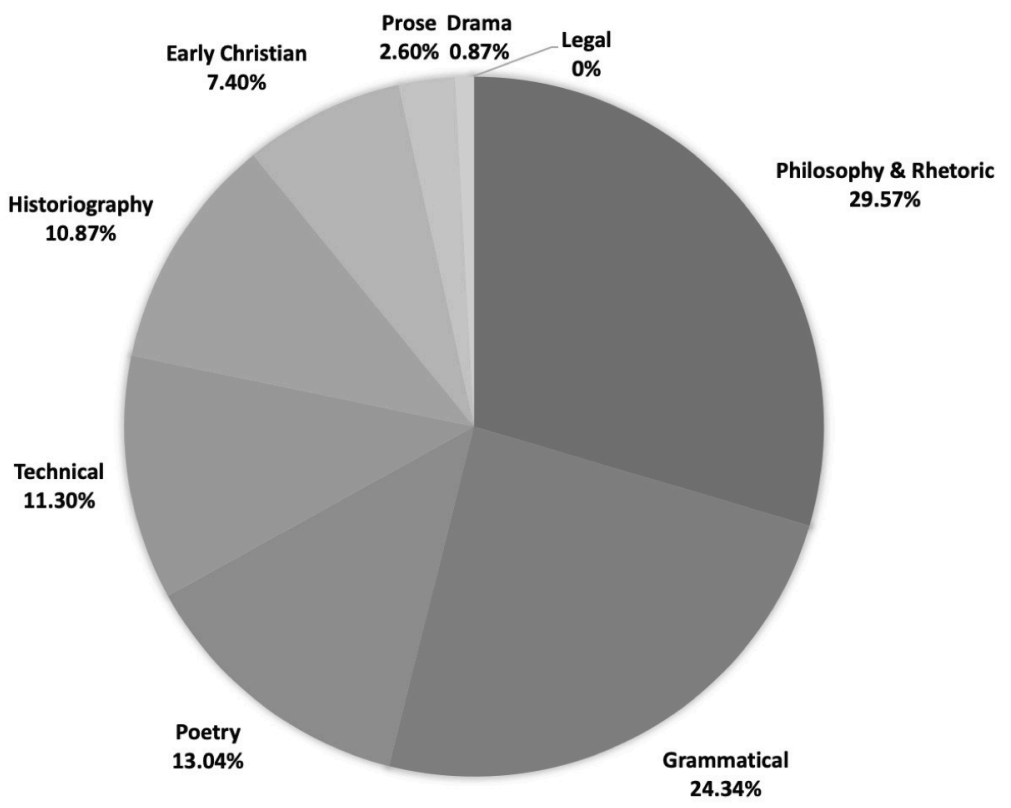

Fig. 6. The percentage of occurrence of the word portentum in each source category

\subsection{Portentum}

The word portentum is ranked third in terms of frequency of its use, accounting for $15.45 \%$ of the attestations (see fig. 1). It appears almost as often in 'divinatory' and 'various', with a slight advantage in favour of the latter (at least according to my interpretation). Portentum was most often used in philosophical and rhetorical works (29.57\%) and grammatical $(24.34 \%)$. But if we take into account only the 'divinatory' context, portentum describing the interference of the gods in the human world is more frequently encountered in historiographic ( $88 \%$ of cases of portentum being used in an 'divinatory' context) and grammatical (62.5\%).

In other categories of sources, portentum has been more frequent in 'various' contexts, although the number of attestations of this word is not impressive: some authors do not have that word at all, while others have single attestations. Cicero stands out against this background, in whose works we note $23.9 \%$ of all portentum examples of the Latin sources, and he 
has raised the numbers of occurences in philosophical and rhetorical source category. However, in a 'divinatory' context, portentum is mainly used in one work, De divinatione, while in speeches and letters this phrase is more often used in a rhetorical sense to describe a political opponent or to express a negative attitude to someone's actions or decisions.

In the 'various' context, portentum, more often than prodigium, also served to describe something disgusting or deformed (e.g. the first and unsuccessful attempts by the Earth to create life in Lucr. V 837), obscene things (e.g. obscene acts on stage in Val. Max. II 4.1) and peculiarities (e.g. the concept of the inhabited Moon in Cic. Luc. 123).

\subsection{Ostentum}

Ostentum was a word rarely used by the Latin authors: its percentage share in the total number of the four studied terms is $10.68 \%$ (see fig. 1 ) and $19.1 \%$ in 'divinatory' context (see fig. 2). Nevertheless, $89.94 \%$ of the attestations of this word belongs exclusively to the context of 'divinatory' (143 of 159 attestations of ostentum), which makes it the most homogeneous in terms of meaning.

Ostentum is to be found in philosophical and rhetorical sources: $25.16 \%$. The second place is taken ex aequo by historiographic and technical sources $(21.38 \%)$. These values, however, result from the fact that in each of these categories there was one author who showed an exceptional predisposition to use the word, and these were, respectively: Cicero (24.53\% of all attestations of ostentum), Suetonius (11.32\%) and Pliny the Elder (18.87\%). Most other authors seem to have ignored this word, with occasional exceptions. Consequently, by examining the meaning of ostentum, we examine how these three authors understood the term. Although we are also dependent on the state of preservation of the sources in the case of prodigium, portentum and monstrum, we find them in the works of a larger number of authors, which, with all the limitations, makes the study more credible. 


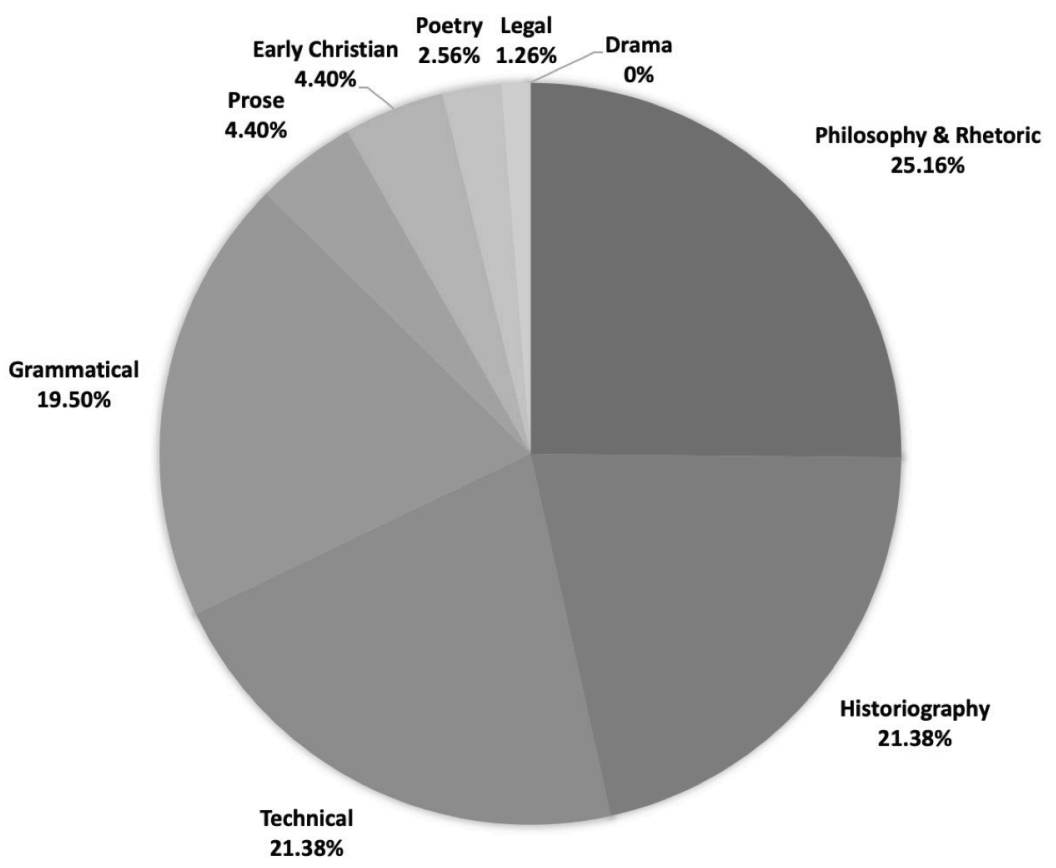

Fig. 7. The percentage of occurrence of the word ostentum in each source category

\subsection{Monstrum}

Of the four words under research, monstrum is the most common term to be found in the Latin ancient sources. It represents $44.06 \%$ of the examples from the dataset of words examined in this article (see fig. 1), but only $18.56 \%$ if the 'divinatory' context shall be taken into account (see fig. 2).

Monstrum appears most often in 'Poetry' (45.43\% of all attestations of the word mostrum); but in this category $86.58 \%$ of the words monstrum are used in 'various' context. This is due to the fact that the theme of Latin poetry was mainly mythological events and characters (monsters killed by Hercules, the Minotaur, the Sphinx). Ovid and Statius made the greatest use of this term (in both cases the use of the word in 'various' contexts prevails). Behind them is Virgil, in whom, despite the predominance of the use of monstrum in 'various' contexts, the context of 'divinatory' also appears 


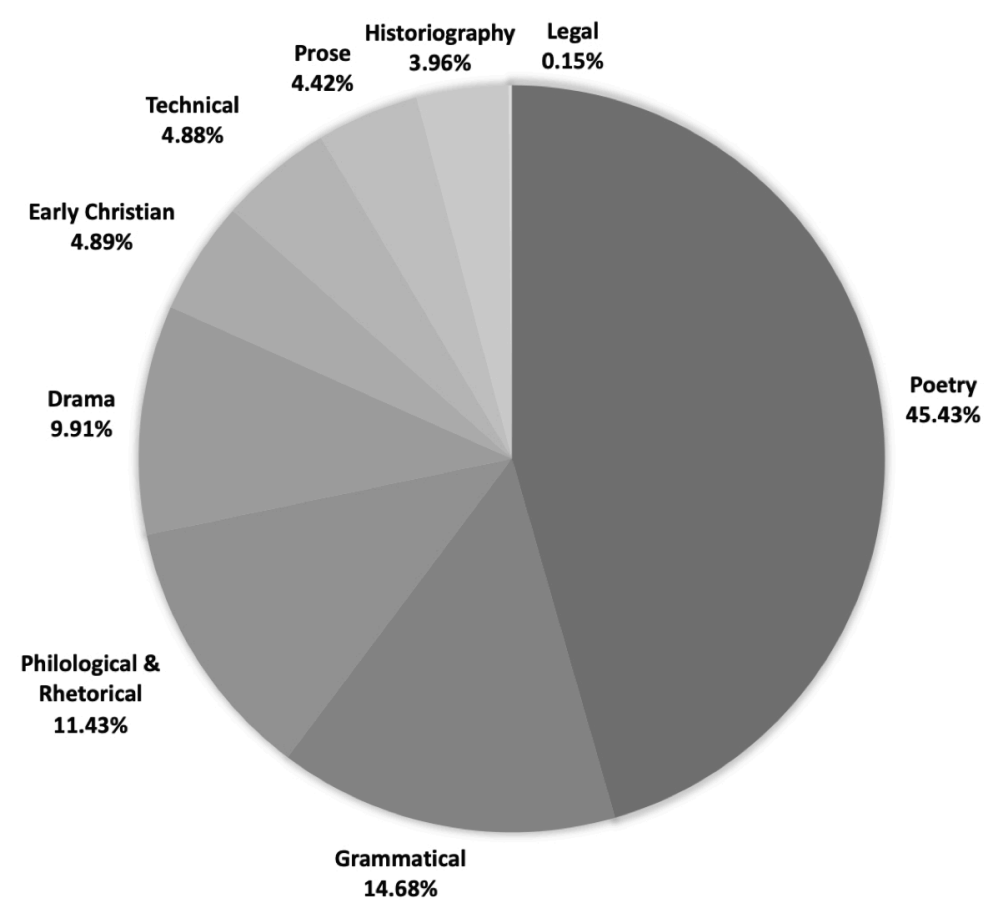

Fig. 8. The percentage of occurrence of the word monstrum in each source category

quite often (Virgil works contain $32.5 \%$ of all monstrum's attestations in the context of 'divinatory' in the category 'Poetry').

The grammatical works contain $14.68 \%$ of the attestations of this word. This result is caused by its presence in etymological definitions. In philosophical and rhetorical sources the use of the word monstrum is $11.43 \%$, occurring mainly in Cicero and Pseudo-Quintilian. Although in this category the term is mainly in 'various' context, in contrast to poetry it does not describe mythological creatures but political opponents or immoral (in the author's opinion) behaviour of different people.

In drama, it is the word monstrum that is the only one to appear in the noteworthy number ( $94.2 \%$ of the words in the category 'Drama'), with $69.56 \%$ of them coming exclusively from Seneca the Younger. The notion of Seneca's monstrum described not only mythological creatures, but also criminal acts (Sen. Phaed. 898) and the destructive force attached to the 
heroes of his tragedy, which pushed them to the commital of the crime (e.g. Medea's monstrum: Sen. Med. 675).

The above data clearly shows that each of the words in question can occur in a 'divinatory' and 'various' context. None of them can be assigned to only one category, although ostentum was closest to achieving such a status. However, there are some generalisations to be made. Prodigium is arguably the most legitimate to consider as a 'sign from the gods', pertaining to its essential meaning. The presence of so many unambiguous attestations of prodigia in the historiographical sources is not only due to the conservative style of the authors, but to the fact that prodigium was probably the technical term for the 'sign' during the period of the Republic. In other words, I suspect that only the word prodigium, never its synonyms, was in the document submitted to the Senate for acceptance of the 'signs'; and only the word prodigium appeared on the tabula published on the Regia wall. I also think that, for example, when a two-headed infant was born, it was not a prodigium from the very beginning - it only became a prodigium when the official nuntiatio was done on it (I am personally convinced that its ontological status changed when the Senate accepted the report). If my interpretation is correct, it does not deprive Cicero of the right to define with this notion the people whom he despised the most, but it may point out that this was the earliest connotational signifier which the word evoked.

In the case of monstrum, it is clear that its original meaning was associated with the possession of the 'inhuman' body (a deformed, unusual or even hybrid), and the 'divinatory' is a secondary meaning of this. Equally so, prodigium, portentum, and monstrum could be used to create invectives; though the semantic range of ostentum did not reach so far.

The linguistic usage of these four terms did not vary over time (for example, the use of the words in the 'divinatory' or 'various' context was more frequent at different times). These differences were due to the unequal state of preservation of the particular source categories - some of them disappeared completely in Late Antiquity, so it is difficult to make reliable comparisons. In the Republican material, whereas, the authors used all these 
terms both in the context of 'divinatory' and 'various'; so it is not even possible to indicate the moment of some 'change' when 'religious' vocabulary took on a 'common' meaning. If there was such a turning point in the history of the Latin language, it would have had to precede our preserved sources. The only discrepancies are related to the word ostentum: during the late Republic and early Empire, we find it more widely in use. However, in view of the fact that this peak in popularity is made up by three prolific authors, I would not conclude from this that the importance of the word has increased during that period. Most authors, apart from the Grammarians, did not use it at all, either during the period of the Republic or at the end of Antiquity.

\section{Definitions of the Grammarians}

Several ancient definitions of the words prodigium, portentum, ostentum, and monstrum have been preserved. It would seem that consequently, there should be no difficulty in determining the meaning of these words, since the Ancients themselves explained them to us in a precise manner. In fact, every study that refers to this terminology starts with an analysis of these definitions - which seems justified. To this end, I divided them into the following groups: 1) Etymological definitions (deriving the meaning of the four words in question from verbs or their derivative forms); 2) Definitions indicating referent (denotation); 3) Definitions indicating connotation; 4) "Hybrid" definitions.

\subsection{Etymological definitions}

The oldest material contains the definition preserved in Festus' De verborum significatu:

Festus $122(\mathrm{~L}):^{9}$ Monstrum, ut Aelius Stilo interpretatur, a monendo dictum est, velut monestrum. Item Sinnius Capito, quod monstret futurum, et mone-

${ }^{9}$ Festus, De verborum significatu que supersunt cum Pauli Epitome, W. M. Lindsay (ed.) [Bibliotheca Scriptorum Graecorum et Romanorum Teubneriana], editio stereotypa, Stutgardiae - Lipsiae 1997. 
at voluntatem deorum; quod etiam prodigium, velut praedictum et quasi praedicium, quod praedicat eadem, et portentum, quod portendat et significet. Inde dici apparet id quartum, quod mihi visum est adiciendum, praesertim cum ex eadem significatione pendeat, et in promptu sit omnibus, id est ostentum; quod item ab ostendendo dictum est apud auctores. ${ }^{10}$

According to Aelius Stilo, monstrum comes from monendo ('warning'), we also say * monestrum. Sinnius Capito further specifies, that (we say monstrum), because (it) shows the future and gives the premonition of the will of the gods. Therefore, we also say prodigium as well as praedictum ('something said in advance', 'a forewarning') and quasi praedicium, because it predicts these same things, and portentum, because it foreshadows and gives signs. As for the fourth word, which it seemed to me good to add here, because it is linked above all to this meaning, and that everyone knows it, this word is ostentum; it was formed by the authors from ostendendo ('manifesting'). (transl. DL)

Considering the names of two Grammarians - Aelius Stilo (2nd/1st c. BCE) and Sinnius Capito (1st c. BCE) ${ }^{11}$ - the content paraphrased by Festus can be dated at least to the end of first century BCE. It appears from the passus that both Grammarians started a discussion on the word monstrum, deriving it from the verb monere (the quotation contains its gerundium: monendo). Sinnius Capito added another possibility: monstrare 'to show [the future]' (monstret futurum). ${ }^{12}$ An alternative expression, monestrum, is a form attested only in Paulus' Epitome (De verborum manuscripts contain monectrum [Vat. Lat. 1549] and monectium [Vat. Lat. 3369]). From the meaning of the verb monere 'to warn' is derived an interpretation of monstrum: it is meant to warn of the intentions of the gods. The verb monstrare ("to show') indicates a slightly different meaning of monstrum ('showing the future'). Although it can be said that the semantic fields of these verbs intertwine - since the gods influence the fate of the world, warnings about their decisions are in some ways tantamount to precepts of the future-monstrare

\footnotetext{
${ }^{10}$ Cf. Festus (Pauli) 125 (L): 'Monstrum dictum velut monestrum, quod moneat aliquid futurum; prodigium velut praedicium, quod praedicat; portentum, quod portendat; ostentum quod ostendat.'

${ }^{11}$ R. A. Kaster, 'Sinnius Capito', [in:] H. CAnciK, H. Schneider (eds.), Brill's New Pauly, consulted online on 23 October 2020.

${ }^{12}$ See R. MAltby, A Lexicon of Ancient Latin Etymologies [= ARCA Classical and Medieval Texts, Papers and Monographs 25], Leeds 1991, s.v. 'monstrum', p. 392: 'a monere vel monstrare').
} 
however is more neutral ('warning' clearly indicates that things do not bode well for the future).

The section on prodigium and portentum is not directly linked to the names proposed by of the Grammarians, but it can be assumed that their discussion extended to these words as well. Prodigium is juxtaposed (like monstrum and monestrum) with the terms considered to have been synonymous, praedictum and quasi praedicium, derived from praedicare ${ }^{13}$ 'to say before,' 'to fortel.' All three of them are supposed to 'say before' about eadem, that is, as far as I understand, aforesaid 'the will of the gods.' The transition of ' $c$ ' in the root word into ' $\mathrm{g}$ ' in the word prodigium required clarification, but these was done elsewhere in the Festus' lexicon. ${ }^{14}$ Portentum was derived from portendere ${ }^{15}$ 'to indicate (some future events), and the meaning is further specified by the verb significare ${ }^{16}$ 'to indicate by physical signs.'

The most interesting is the mention of the fourth word - ostentum. The quotation indicates that this information was added by the author, so the original definition included only the words monstrum, prodigium, and portentum. But which author made this addition? Certainly not Festus: a fourpart definition appears in Cicero (see below), so Verrius Flaccus, the direct source of Festus, could not have made this innovation. I suspect that this part of the sentence comes from Varro's Antiquitates and the statement in 1.sing. ('quod mihi visum est adiciendum') is an original quote from his work. In other words, Varro's master, Aelius Stilo, and Sinnius Capito, who was active during Varro's time, developed (or modified an already existing) definition concerning monstrum, prodigium, and portentum, while Varro added a fourth term, ostentum, of a meaning close to the three mentioned above, and created according to the same derivation principles: ostentum from ostendere ${ }^{17}$ 'to present', 'to display' (gerundium: ostendendo). The very idea of linking ostentum to ostendere already existed independently (apud

${ }^{13}$ OLD, s.v. 'praedico (2)', p. 1428.

${ }^{14}$ Festus 254 (L): 'Prodigia quod prodicunt futura, permutatione g. litterae; nam quae nunc c. appellatur, ab antiquis g. vocabatur' ('Prodigia because they predict the future. There was an alliteration of "g": what today is pronounced "c", the ancients had pronounced "g"'; transl. DL).

${ }^{15}$ OLD, s.v. 'portendo', p. 1407.

${ }^{16}$ OLD, s.v. 'significo', p. 1758.

${ }^{17}$ OLD, s.v. 'ostendo', p. 1274. 
auctores). In any case, I think that Varro has completed the definition of his master, so I will refer to the four-part definition as 'Varro's definition'.

Cicero twice quoted a definition of these four concepts, paraphrasing, in my view, nothing else but 'Varro's definition':

Cic. ND. II $7:^{18}$ Praedictiones vero et praesensiones rerum futurarum quid aliud declarant nisi hominibus ea quae futura sint ostendi monstrari portendi praedici? ex quo illa ostenta monstra portenta prodigia dicuntur.

Again, prophecies and premonitions of future from the fact of divination. Events cannot but be taken as proofs that the future may appear (ostendi) or be foretold as a warning (monstrari) or portended (portendi) or predicted (praedici) to mankind - hence the very words 'apparition', (ostenta) 'warning', (monstra) 'portent', (portenta) 'prodigy' (prodiga).

Cic. DD. I 93: ${ }^{19}$ Quorum quidem vim, ut tu soles dicere, verba ipsa prudenter a maioribus posita declarant. Quia enim ostendunt, portendunt, monstrant, praedicunt, ostenta, portenta, monstra, prodigia dicuntur.

Indeed, the inherent force of these means of divination, as you like to observe, is clearly shown by the very words so aptly chosen by our ancestors to describe them. Because they 'make manifest' (ostendunt), 'portend' (portendunt), 'intimate' (monstrant), 'predict' (praedicunt), they are called 'manifestations', 'portents', 'intimations', and 'prodigies'.

Cicero, mentioning the derivation of monstrum, decided to derive it from monstrare; besides, he did not go beyond what we have already seen in 'Varro's definition.'

Varro (or at least the authority of his name) is invoked by Servius in Commentary on the Aeneid:

Serv. Aen. III 366: ${ }^{20}$ Prodigium canit: prodigium, portentum et monstrum modico fine discernuntur, sed confuse pro se plerumque ponuntur. Varro sane haec ita definit: 'ostentum, quod aliquid hominibus ostendit; portentum,

${ }^{18}$ Text and translation: Cicero, On the Nature of the Gods, [in:] Cicero, On the Nature of the Gods; Academics, H. RAскнам (ed. \& transl.) [= The Loeb Classical Library 268], Cambridge MA - London 1933 [1951], pp. 128-129.

${ }^{19}$ Text and translation: Cicero, De divinatione, [in:] Cicero, De senectute; De amicitia; De divinatione, W. A. FAlConer (ed. \& transl.) [= The Loeb Classical Library 154], Cambridge MA - London 1923, pp. 324-325. 
quod aliquid futurum portendit; prodigium, quod porro dirigit; miraculum, quod mirum est; monstrum, quod monet'.

'Prodigium foretells': prodigium, portentum, and monstrum are separated by a fine line, but for the most part they are used indiscriminately for each other. ${ }^{21}$ Varro sensibly defined them in this way: 'ostentum, because it shows people something; portentum, because it predicts the future; prodigium, because it directs further (into the future), miraculum, because it is astonishing, monstrum, becauce it warns'. (transl. of Auctus by DL)

The italic part comes from Servius Auctus. It can be seen that the original Servius briefly stated that prodigium, portentum, and monstrum (without ostentum!) are difficult to distinguish and are used interchangeably. Auctus added an etymological definition, which he attributed to the name Varro. The proposal to derive prodigium from praedicere, which had appeared in the earlier tradition, was replaced by porro dirigere - a rather desperate operation requiring the addition of porro to the base verb in order to harmonise the proposed etymology with the term being explained. The translation of this expression is also not entirely satisfactory and requires additional interpretation. In the case of monstrum, Auctus opted for a derivation of monere. A certain novelty is the appearance of the term miraculum in this juxtaposition. Although it is entirely plausible that Varro made reference to this word in his works, placing it on a par with the four terms discussed in this paper is a rather late innovation (see below).

In Augustine's text, the part with definitions is preceded by the discussion of a passus in Varro's De gente populi Romani. In that work, Varro called the Morning Star, which once had been observed to change size and colour, to be portentum. The use of the word portentum prompted Augustine to engage in a discussion about other synonymous words:

Aug. CD. XXI 8: ${ }^{22}$ Unde illorum quoque miraculorum multitudo silvescit, quae monstra ostenta portenta prodigia nuncupantur. Quae recolere et com-

\footnotetext{
${ }^{20}$ Servius, In Vergilii carmina comentarii. Servii Grammatici qui feruntur in Vergilii carmina commentarii, G. Thilo, H. Hagen (eds.) [Bibliotheca Scriptorum Graecorum et Romanorum Teubneriana], Leipzig 1881.

${ }^{21}$ Translation by Remus, 'Does terminology distinguish Early Christian' (cit. n. 4), p. 536.

${ }^{22}$ Edition and translation: Augustine, City of God, Volume 7: Books 21-22, W. M. GreEn (ed. \& transl.) [= The Loeb Classical Library 417], Cambridge MA - London 1972, pp. 56-57.
} 
memorare si velim, huius operis quis erit finis? Monstra sane dicta perhibent a monstrando quod aliquid significando demonstrent, et ostenta ab ostendendo, et portenta a portendendo, id est, praeostendendo, et prodigia quod porro dicant, id est, futura praedicant.

From this power comes the wild profusion of those marvels which are called omens, signs, portents, prodigies. If I should try to recall and enumerate these, where would this treatise end? The various names monstra, ostenta, portenta, prodigia come from the verbs monstrare 'show', because they show something by a sign, ostendere 'display', portendere 'spread in front', that is, display beforehand, and porro dicere 'say aforetime', that is, predict the future.

In the Augustinian version of the definition, as far as the changeable elements are concerned, monstrum is taken from monstrare, and prodigium from porro dicere, which is probably the more correct, not yet distorted version of Auctus' porro dirigere, and corresponds semantically to praedicere (by transcribing the source containing the praedicere variant it can be easily paraphrased as porro dicere). Augustine takes portentum not only from portendere, but also from the alternative praeostendere. In my opinion, the presence of miracula at the beginning of this passus could be one of the ways of explaining why 'Varro's definition' in the Auctus version contains this additional element.

While it is unlikely to be clear where Augustine derived this definition from (from Varro's Antiquitates or De gente populi Romani? from Cicero?), Isidore, who made extensive use of De civitate Dei, ${ }^{23}$ most likely made considerable use of Augustine's work in this place, although he also used separate material:

Isid. Orig. XI 3.2: ${ }^{24}$ Nam portenta dicta perhibent a portendendo, id est praeostendendo. Ostenta autem, quod ostendere quidquam futurum videantur. Prodigia, quod porro dicant, id est futura praedicant. Monstra vero a monitu dicta, quod aliquid significando demonstrent, sive quod statim monstrent quid appareat; et hoc proprietatis est, abusione tamen scriptorum plerumque corrumpitur.

${ }^{23}$ S. A. BARney, 'Introduction', [in:] S. A. BARney et al. (eds. \& transl.), The Etymologies of Isidore of Seville, New York 2006, p. 12.

${ }^{24}$ Edition: Isidore, Etymologiarum sive Originum Libri XX, vol. II (libri XI-XX), W. M. LINDSAY (ed.) [Scriptorum Classicorum Bibliotheca Oxoniensis], Oxford 1911. 
The term'portent' (portentum) is said to be derived from foreshadowing (portendere), that is, from 'showing beforehand' (praeostendere). 'Signs' (ostentum), because they seem to show (ostendere) a future event. Prodigies (prodigium) are so called, because they 'speak hereafter' (porro dicere), that is, they predict the future. But omens (monstrum) derive their name from admonition (monitus), because in giving a sign they indicate (demonstrare) something, or else because they instantly show (monstrare) what may appear; and this is its proper meaning, even though it has frequently been corrupted by the improper use of writers. ${ }^{25}$

In Isidore, everything is in line with Augustine's version except for the part about the etymology of monstrum, which he supplemented to a certain extent with a derivation from monere: the word monstrum was derived from monitus, but the activity that monstrum performs is demonstrare or monstrare. As far as this is concerned, Isidore categorically states that 'showing what may appear' is the only proper meaning of this word; and that it had been constantly abused by other authors (which probably means that, according to Isidore, monstrum was used incorrectly in virtually all Latin poetry).

In addition, we find a specific definition of ostentum twice in Festus:

Festus 218 (L): Ostentum, quo nunc utimur interdum prodigii vice, quin participialiter quoque dici solitum sit, non dubium facit etiam C. Gracchus de legibus a se promulgatis, cum ait: 'Quod unum nobis inostentum, ipsis inusum adportatur'.

Ostentum, which we now sometimes use instead of prodigium; that it was also commonly used as a participle [of ostendo], is proved beyond doubt even by $\mathrm{C}$. Gracchus [in the speech] on laws promulgated by him, when he says: 'which is the only thing conveyed not shown to us [negation + participle of ostendo] and not used by them'.

The definition equates the meaning of ostentum with prodigium, while indicating that the form of ostentum is a participle; the attached example concerns precisely the basic meaning of the verb ostendere, unrelated to

\footnotetext{
${ }^{25}$ Translation: Isidore, The Etymologies (cit. n. 23), pp. 243-244.

${ }^{26}$ Translation: Fragmentary Republican Latin: Oratory, Part I, G. MANuwALd (ed. \& transl.)

[= The Loeb Classical Library 540], Cambridge MA - London 2019, p. 305.
} 
a 'divinatory' context. Festus cited two other examples where ostentum is only a participle:

Festus 214 (L): Ostentum non solum pro portento poni solere, sed etiam participialiter [...] testimonio est Pacuvius in Medo (238): 'Atque eccum in ipsotempore ostentum senem'. Et Accius in Bacchis (252): 'et praesens praesto irrideris nobis [...] stipe ultro ostentum obtulit'.

'Ostentum.' That this word is used not only for a portent but also as a participle [...] Pacuvius is a witness in Medus - 'Why, see him! There in the very nick of time / The old man is disclosed. ${ }^{27}$ Accius bears witness in The Bacchanals -'In person then and there he showed himself, / And, smiling gently, of his own free will, / Offered himself to us astonished men' ${ }^{28}$

\subsection{Definitions indicating referent}

The second category of definitions are those that tend to attribute the terms prodigium, portentum, ostentum, and monstrum to specific phenomena (referents).

According to Augustine and Isidore, Varro defined portentum as something 'contrary to nature' (contra naturam):

Aug. CD XXI 8: Hoc certe Varro tantus auctor portentum non appellaret nisi esse contra naturam videretur.

As great a writer as Varro would surely not call this a portent unless it seemed contrary to nature. ${ }^{29}$

Isid. Etym. XI 3.1: Portenta esse Varro ait quae contra naturam nata videntur (...).

Varro defines portents as beings that seem to have been born contrary to nature $(\ldots .)^{30}$

${ }^{27}$ Translation: Remains of Old Latin, Volume 2: Livius Andronicus. Naevius. Pacuvius. Accius, E. H. WARmington (ed. \& transl.) [= The Loeb Classical Library 314], Cambridge MA - London 1936, p. 259.

${ }^{28}$ Translation: ibidem, p. 399.

${ }^{29}$ Translation: Augustine, City of God (cit. n. 22), p. 51.

${ }^{30}$ Translation: Isidore, The Etymologies (cit. n. 23), p. 243. 
Unfortunately, the wording contra naturam does not solely belong to the definition of portentum. In Digest (Book L) we find a definition of ostentum. Ulpianus in On the Edict quoted it from some of the works of the jurist Marcus Antistius Labeo:

Dig. 50.16.38 (Ulpianus:) ${ }^{31}$ 'Ostentum' Labeo definit omne contra naturam cuiusque rei genitum factumque. Duo genera autem sunt ostentorum: unum, quotiens quid contra naturam nascitur, tribus manibus forte aut pedibus aut qua alia parte corporis, quae naturae contraria est: alterum, cum quid prodi-

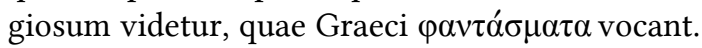

On the Edict, Book XXV: Labeo defines the term 'prodigy' (ostentum) to mean everything which is born or produced contrary to nature. There are, however, two kinds of prodigies (ostentorum); one where something is born contrary to nature, for instance with three hands or feet, or with some other part of the body deformed; another, where something is considered to be unusual, and which the Greeks designate fantasmata, that is to say, apparitions. $^{32}$

The definition is potentially one of the more interesting ones that the Ancients gave us. It could have been constructed for the purposes of pontifical law, unlike the discourse of the Antiquarians and Grammarians. It may also have been taken from Labeo's Libri de iure pontificio by Ulpianus; but unfortunately we do not know what element from the Edictum praetoris he wanted to comment on by quoting it. The Commission, which had the task of compiling the Digest, then re-used it - thus, the definition that we have has been extracted at least twice from the original context.

Unfortunately, for a specialist definition, its definiens is astonishingly lacking in precision: it splits the explanation of definiendum's part into two possibilities and, in addition, in the second one there are notions that also

${ }^{31}$ Edition: Corpus iuris civilis, P. Krueger, T. Mommsen (eds.), vol. 1, Berlin 1908.

${ }^{32}$ Translation: S. P. ScotT, The Civil Law, vol. 11, Cincinnati 1932, available online at https://droitromain.univ-grenoble-alpes.fr/Anglica/D50_Scott.htm. Cf. A. WATson, The Digest of Justinian, vol. 4, Philadelphia 1985 [1998], p. 450: 'Labeo defines ostentum as everything done contrary to the nature or inborn characteristics of anything. However, there are two kinds: one, whenever somethig unnatural is born, as, for instance, with three hands or feet or with some other part of the body which is unnatural; second, if something appears fantastic, which the Greeks call phantasmata' (Watson's translation). 
need to be clarified (prodigiosum, $\varphi \alpha v \tau \alpha \dot{\sigma} \sigma \alpha^{33}$ ) - that is the error of defining ignotum per ignotum. This is the case if we consider the citation quoted above to be a coherent entity. In my opinion, however, only a short sentence comes from Labeo: 'omne contra naturam cuiusque rei genitum factumque'. I think that the section on two types of ostenta is a comment by Ulpianus. I also suspect that the information about $\varphi \alpha v \tau \alpha$ ó $\mu \alpha \tau \alpha$ is a later addition, perhaps added at the stage of compiling Digesta. If I am right, Labeo has briefly defined ostentum as something contra naturam.

In my opinion, Ulpianus wanted to clarify what contra naturam means. The first of the possibilities that he gave us - that it is a creature with a deformed body - is found in a slightly different form in Suetonius:

Suet. Pratum, verborum differentia, 284 (s.v. ostentum) $:{ }^{34}$ Ostentum sine corpore solido nobis se ostendit et oculis et auribus obicitur, ut interdiu tenebrae, nocte lux; prodigium quod solidis corporibus conspicitur, ut in caelo cometae stella aut fax; monstrum quod [contra] naturam cognitam egreditur, ut serpens cum pedibus, avis cum IIII alis.

Ostentum shows itself to us without an integral body and appears to our eyes and ears, as well as darkness during the day or light at night. Prodigium (is the one) in which you can see an integral body, like a comet in the sky or a meteorite. Monstrum (it is) what comes up against the commonly understood nature, like a snake with feet or a bird with four wings. (transl. DL)

According to Suetonius' division, ostentum is an intangible and unnatural phenomenon (at least the examples he gave are not natural, although he did not call them contra naturam). Prodigium is tangible and natural, although unusual. Monstrum is something 'contrary to nature' (contra naturam), something with a deformed body, like animals with extra limbs. Thus monstrum as defined by Suetonius is the same as ostentum to be found in the definition of Labeo-Ulpianus.

\footnotetext{
${ }^{33}$ LSJ [Liddell-Scott-Jones], s.v. $\varphi \alpha ́ v \tau \alpha \sigma \mu \alpha$ : 'apparition, phantom, vision, dream, pl., phenomena, pl., portents.'

${ }^{34}$ Edition: Suetonius, Differentiae sermonum Remi Palaemonis ex libro Suetonii Tranquilli, qui inscribitur pratum, [in:] C. Suetoni Tranquilli quae supersunt omnia, C. L. Rotн (ed.) [Bibliotheca Scriptorum Graecorum et Romanorum Teubneriana], Leipzig 1875.
} 
Traces of Suetonius' definition can be found in Festus' lexicon (in Paulus' Epitome). One of his definitions of monstrum corresponds to that of Suetonius:

Festus (Pauli) 147 (L): Monstra dicuntur naturae modum egredientia, ut serpens cum pedibus, avis cum quattor alis, homo duobus capitibus, iecur quom distabuit in coquendo.

We call a monstrum that which goes beyond the measure of nature, like a snake with legs, a bird with four wings, a human with two heads, a liver that melts during cooking. (transl. DL)

Despite the agreement of both authors on the nature of monstrum, this agreement does not come in the definition of portentum as noted by Festus (Paulus):

Festus (Pauli) 285 (L): Portenta rerum: fieri dicuntur, cum solida corpora raro se ostendunt, ut cometae, turbines, barathra, sereno caelo facta tonitrua.

Portenta rerum: They are said to form when they rarely manifest themselves in an integral body, like comets, whirlwinds, precipices, lightning formed from the serene sky. (transl. DL)

Portenta are supposed to be without an integral body, like ostentum according to Suetonius, and at the same time they are described as natural phenomena by which Suetonius defined prodigium.

The definition from Suetonius' Pratum almost in unaltered form found its way to the collection De proprietate sermonum vel rerum,${ }^{35}$ which the editor of the text, Myra Uhlfelder, dates to the fourth-fifth century CE. ${ }^{36}$ Uhlfelder pointed out that Verrius Flaccus (hence part of this definition can be found in Festus), Pliny the Elder (Libri Dubii Sermonis) ${ }^{37}$ and Grammarian

${ }^{35}$ PSR 217: 'Inter ostentum et prodigium et monstrum hoc interest, quod ostentum sine corpore solido nobis se ostendit et oculis et auribus obicitur, ut interdiu tenebrae, nocte lux; prodigium vero quod solidis corporibus conspicitur, ut in caelo cometes aut stella aut fax; monstrum vero contra naturam cognitam egreditur ut serpens cum pedibus, avis cum quattor alis (edition: M. L. Uhlfelder, De proprietate sermonum vel rerum. A Study and Critical Edition of a Set of Verbal Distictions [= Papers and Monographs of the American Academy in Rome 15], Rome 1954).

${ }^{36}$ Uhlfelder, De Proprietate sermonum vel rerum (cit. n. 35), p. 25.

${ }^{37}$ Plinius Secundus, Librorum dubii sermonis VIII reliqiae, J. W. BECK (ed.) [Bibliotheca Scriptorum Graecorum et Romanorum Teubneriana], Leipzig 1894. 
Flavius Caper ( $f$ l. 2nd c. CE) must have played a role in the transmission of this text. ${ }^{38}$ De proprietate sermonum was considered to be the third part of Isidore's De differentiis until the mid-nineteenth century. Today his authorship is attributed to only two books. ${ }^{39}$ In Book I (often referred to as inter aptum / inter caelum) there is the following definition:

Isid. Diff. I $457:^{40}$ Inter portentum, et monstrum: portentum est, quod ex formis diversis proponitur: monstrum, quod extra naturam nascitur, vel nimis grande, vel nimis breve.

The (difference) between portentum and monstrum: a portentum is what is presented in different shapes, while monstrum is what is born outside of (the course of) nature, either too big or too small. (transl. DL)

The phrase extra naturam concerning monstrum can be equated with contra naturam in the previous definitions. However, on the basis of this description, portentum can also be considered as something contra naturam, because 'different shapes' somehow must go beyond 'normal' or 'standard' shapes of creatures or phenomena.

\subsection{Definitions indicating connotation}

In this category, I have included definitions which, in my opinion, instead of defining 'what is' the phenomenon called by one of the four terms in question, indicate 'in which associative sphere' the term existed. One of them is in Appendix Probi. According to Carl Barwick, Appendix is a remnant of the lost

\footnotetext{
${ }^{38}$ UhlFelder, De proprietate sermonum vel rerum (cit. n. 35), p. 32.

${ }^{39}$ C. CodoñER, 'Historia del texto del libro I de las Differentiae de Isidoro de Sevilla', Revue d'histoire des textes 14-15 (1984-1985), pp. 77-95; M. A. ANDRÉs SANZ, 'Relación y transmisión manuscrita de los tres libros de Differentiae editados en P.L. 83 (Isidoro de Sevilla)', Revue d'histoire des textes 30 (2000), pp. 239-262; C. FraGA, 'Isidore of Seville as a grammarian', [in:] A. FEAR, J. Wood (eds.), A Companion to Isidore of Seville, Leiden - Boston 2020, pp. 228-235.

${ }^{40}$ Edition: Isidorus, Differentiae, [in:] Patrologia Latina LXXXIII, J.-P Migne (ed.), Paris 1862. Newer edition of book I: Isidoro de Sevilla, Diferencias, libro I. Introducción, edición crítica, traducción y notas, C. CODOÑER (ed.) [Les Belles Lettres], Paris 1992.
} 
work of the Instituta Artium of the fourth-century Grammarian Probus, ${ }^{41}$ so I shall retain this identification, without naming the author as Pseudo-Probus:

Prob. Appendix Probi. [Gram. Lat. IV. 200]: $:^{42}$ Inter ostentum et monstrum et prodigium et portentum hoc interest, quod ostentum et monstrum praesentia ostentat, prodigium autem et portentum futura significat.

There is such a difference between ostentum, monstrum, prodigium, and portentum: ostentum and monstrum point to the present, while prodigium and portentum give signs for the future. (transl. DL)

Probus did not derive these terms (and their meanings) from verbs, nor did he try to describe the phenomena they would refer to. Instead, he indicated the general spheres with which he associated these terms: ostentum and monstrum were to be associated with events taking place in the present (perhaps the idea that ostendere and monstrare should 'indicate' something that already exists, but there is no such explanation in the definition itself), and he associated prodigium and portentum with the future (perhaps because in the definitions of other Grammarians they were often accompanied by porro), thus placing them in the category of predictive signs.

Non. 701-702 (L): $:^{43}$ Monstra et prodigia et portenta hoc distant, quod sunt monstra ostenta et monita deorum. Vergilius lib. III in (Aen., 58): 'primumque parentem / monstra deum refero, ${ }^{44}$ prodigia deorum minae vel irae. Vergilius Aen. lib. III (365): 'sola novum dictuque nefas harpyia Celaeno / prodigium canit' et lib. VI (379): 'prodigiis acti caelestibus ossa piabunt'. Portenta ostenta quae aliquid inminere significant. Lucilius lib. XXVI (34): 'nisi portenta anguisque volucres ac pinnatos scribitis'.

Monstra, prodigia, and portenta differ as follows: monstra are the instructions and warnings of the gods (...), prodigia are (a kind of) threats or anger of gods (...), portenta are indications of some imminent danger (...). (transl. DL)

${ }^{41}$ UhlFELder, De proprietate sermonum vel rerum (cit. n. 35), p. 19.

${ }^{42}$ Grammatici Latini, vol. 4, H. KeIL (ed.) [Bibliotheca Scriptorum Graecorum et Romanorum Teubneriana], Leipzig 1864.

${ }^{43}$ Edition: Nonius Marcellus, De compendiosa doctrina libri XX, vols. 2-3, W. M. LiNDSAY (ed.) [Bibliotheca Scriptorum Graecorum et Romanorum Teubneriana], Leipzig 1903.

${ }^{44}$ Cf. Non. 554.39-40 (L): Monstrum, monstrationem. Vergilius Aen. lib. III (59): 'monstra deum refero'. 
According to the definition provided by Nonius, monstra, prodigia, and portenta are a type of warning from the gods ('divinatory' context), although its description does not allow for their precise distinction. In two other places Nonius juxtaposes monstrum with somethig 'dreadful' (horrendum). ${ }^{45}$

\section{4. 'Hybrid' definitions}

I have labeled a large group of definitions as 'hybrids', because in the form in which they survive, they are composed of several smaller definitions (etymological, indicating both referent and connotation).

Festus 284 (L): Portenta existimarunt quidam gravia esse, ostenta bona: alii portenta quaedam bona, ostenta quaedam tristia appellari. Portenta, quae quid porro tendatur, indicent: ostenta, quae tantummodo ostendant; monstra, <quae> praecipiant quoque remedia.

Portenta: some people think that this word refers to something unfavorable, while the word ostenta refers to something favorable. The others called portenta as fortunate, but ostenta as unfortunate. One would name portenta as being those which mark what is 'stretched forward' (porro tendatur); ostenta, those which only reveal what is (at present); and monstra, those which also prescribe remedies for evil. (transl. DL)

The greater part of this definition indicates what the above-mentioned terms were associated with - the announcement of something favorable or unfavorable (and as you can see from the example of Festus, even in this respect ancient definitions do not make it easier to determine their meaning). There are also elements taken from etymological definitions: the meaning of portentum derives the meaning of the verb porro tendatur, 'stretch forward' (about ostentum and the interpretation of ostendere, see above Appendix Probi). The construction of the definition indicates that we are dealing here with

\footnotetext{
${ }^{45}$ Non. 554.36-38 (L) 'Monstrum dicitur horrenda magnitudo'. Vergilius Aen. lib. III (658): 'monstrum horrendum, informe, ingens'; Non. 839.27-29 (L): 'Mira et miracula veteres pro monstris vel horrendis ponebant' ('The ancestors considered the amazing and miraculous phenomena to be monsters or something terrifying'; transl. DL). Lucilius, Saturarum lib. I (40): 'miracla ciet elephantas'.
} 
a combination of at least two definitions, made by a Grammarian (not necessarily by Festus himself, a previous Grammarian could also have done so).

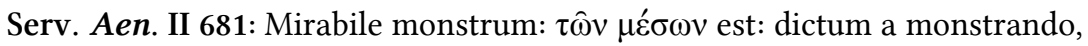
id est monendo. Et refertur ad praesens eius significatio. Prodigium autem est quod in longum tempus dirigit significationem.

Mirabile monstrum: It is an indefinite (i.e. combining the meaning of something terrible, negative, and miraculous, positive) expression: it is thus called from monstrando ('showing'), that is, monendo ('warning'). Its meaning refers to the present. And prodigium is the one whose meaning is derived from the fact that it points to a a long period of time (towards the future). (transl. DL)

Servius first took monstrum from monstrare (Auctus added the variant with monere), then combined it with the function of signalising something about the present (again, it is probably about the connection of monstrare with pointing to something already existing). He linked prodigium with the announcement of what is to happen in the future (from porro).

Non. 693-694. (L): Monstra et ostenta similiter intelleguntur, quod inminentia monstrent et ostendant. Portentum non solum quod portendat, sed quod etiam portenta adportet et faciat ex his significationibus quae in auspiciis, auguriis, extispiciis ostenduntur. Prodigium autem semper pessimum est, dictum quasi porro adigendum. Vergilius lib. III (Aen. 365): sola novum dictuque nefas Harpyia Celaeno / prodigium canit et tristes denuntiat iras.

Monstra and ostenta are understood in a similar way because they 'point' and 'show' the danger. Portentum (has its name) not only because it 'portends' (portendat), but also because the portenta 'brings' (adportent) and emerges from those signs that are given through auspicia, augury and extispicy. Prodigium is always something unfortunate, it is thus called from something like 'driving foreward' (porro adigendum) (...). (transl. DL)

Monstrum and ostentum have been taken out of monstrare and ostendere respectively, while portentum of portendere and adportare. Portenta are additionally described as typical signa impetrativa. Prodigium is not only supposed to be a derivative of the 'forward-looking' expression porro adigendum (an interesting proposal, as it tries to deal with the problem of the lack of ' $g$ ' in the root verb), but is associated with the heraldry of misfortune. 
Non. 598.27-30 (L): Portenta dicuntur quae aliquid portendunt, ut saepe. Portenta, inania quaedam et inridenda. Cicero Tusculanarum lib. I (11): aut quid negoti est haec poetarum et pictorum portenta convincere?

Portenta are called those (phenomena) that 'foretell' something, as it often happens. Portenta, things vain and worthy of ridicule (transl. DL). Cicero, Tusculan Disputations I 11: 'Or what trouble is there in proving the falsity of these hobgoblins of poets and painters?' ${ }^{46}$

In this example, Nonius presented a two-part definition, in which he derived the name of the portentum in the first place, and then explained this term should be understood as worthless things - as an example he was given a statement by the protagonist of the dialogue, who disregarded the works of artists. Only the second part of the definition is in logical connection with the example of Tusculan Disputations (and already has the clear features of a typical gloss).

There are two more elaborate definitions in Isidore's De differentiis:

Isid. Diff. I. 458: Inter portentum, et portentosum. Portentum dicitur quod ex omni parte naturae mutationem sumens aliquid portendere futurum videtur, sicut biceps caput in corpus unum, vel sicut in Xerxis regia ex equa vulpem ferunt creatam; per quod eius solvi regnum ostensum est. ${ }^{47}$ Nam portentosa dicuntur quae ex parte corporis sumunt mutationem; ut, exempli causa, cum sex digitis nati, sive cum aliqua pravitate membrorum.

(Difference) between portentum and portentosum: Portentum is called what is changing in relations to every part of its nature, which, to a certain extent seems to announce (portendere) the future, like two heads growing out of the one body, or like the mare that gave birth to a fox in Xerxes' palace - thus indicating the end of his kingdom. Portentosa are called those (cases) in which there is a change in relation to body parts, for example: when someone is born with six fingers or with some kind of limb deformity. (transl. DL)

In this example, Isidore combined the noun portentum and the adjective portentosum. He focused on a careful description and distinction of the cases that each of them refers to, but there is also an element of etymological defi-

\footnotetext{
${ }^{46}$ Translation: Cicero, Tusculan Disputations, J. E. KING (ed. \& transl.) [= The Loeb Classical Library 141], Cambridge MA - London 1927, p. 15.

${ }^{47}$ Cf. Isid. Orig. XI 3.5: 'Xerxen quippe vulpis ex equa creata solvi regnum portendit'.
} 
nition (portendere). He considered as portentum a situation in which there is a serious disorder of the laws of nature and he did not only mean a serious deformity of the body (two heads), but also phenomena that should not normally take place (a mare giving birth to a fox). He gave them the aspect of a predictive sign. He also considered the adjective portentosum to be adequate for describing minor bodily deformities.

Isid. Diff. I. 459: Inter portentum, et ostentum. Portentum nascitur et in sua permanet qualitate: ostentum vero subito offertur oculis, et subducitur. Sic portentum dicitur a portendendo, id est, porro ostendendo, sicut et prodigium, quod porro dicat, id est futura de longe praedicat. Monstrum sane a monitu, vel monstrando dictum, quod aliquid significando demonstret, et statim [monstrent quid appareat - suppl. Isid. Etym. XI 3.3; DL]. Quinque sunt autem genera prodigiorum, ut Varro dicit, id est: portentum, ostentum, prodigium, miraculum, et monstrum.

The (difference) between portentum and ostentum: portentum emerges and remains in that condition. Ostentum suddenly appears before eyes and disappears. Thus portentum is called from 'predicting' (portendendo), that is 'showing forward' (porro ostendendo). The same about prodigium, because it 'speaks forwards' (porro dicat), that is, it predicts a distant future (praedicat). Monstrum they call from 'warning' (monitu) or 'showing' (monstrando) as it points to something by giving sings and it instantly [shows (monstrare) what may appear]. According to Varro, there are five types of prodigia: portentum, ostentum, prodigium, miraculum, monstrum. (transl. DL)

The above definition begins with a delineation of the difference between portentum, something that appears and does not disappear, and ostentum, something that appears only for a moment. Isidore then added an etymological part concerning portentum, prodigium, and monstrum - his material coinciding with the four-part etymological definition included in Etymologiae; and what is more, it needs to be supplemented on the basis of this very text, as the sentence about monstrum is clearly abrupt. Finally, he added 'Varro's definition', according to which prodigium is a higher-order category divided into prodigium in proper-sense, portentum, ostentum, miraculum, and monstrum. The version of 'Varro's definition', including miraculum, is probably taken from Servius' Commentary. 
The last of the definitions discussed in this paper comes from the short anonymous treaty De differentiis. For a long time this work was attributed to Fronto; whereas in modern times it has been attributed to Charisius (as Charis. 388), for Barwick has placed this collection in the edition of Ars grammatica of Charisius as Book V. ${ }^{48}$ However, this is not a commonly accepted identification, ${ }^{49}$ so I will remain with the opinion that we do not know the author of this treaty.
Anon. De differentiis 520.20-27 [Grammatici Latini VII]: $:^{50}$ Ostentum et portentum et monstrum et prodigium. Ostentum quod praeter consue- tudinem offertur, ut puta si videatur terra ardere vel caelum vel mare: por- tentum quod porro et diutius manet futurumque postmodum aliquid signifi- cat: monstrum est contra naturam, ut est Minotaurus: prodigium quod mores faciunt, per quod detrimentum exspectatur. Itaque qui prodigia faciunt pro- digi vocantur, in ostento raritas admirationem facit, in monstro rectus ordo naturae vincitur, in portento differtur eventus, in prodigio detrimenta signi- ficantur. ${ }^{51}$
Ostentum, portentum, monstrum, and prodigium. Ostentum is what occurs against the normal course of things, namely, if the earth or sky or the sea seems to be burning. Portentum is about what is to come and stay for a long time and gives a sign for the future. Monstrum is something going against opposite to nature, just like the Minotaur. Prodigium refers to what results from someone else's wicked habits, which can be expected to cause damage. Therefore, those who make prodigia are called 'wasters' (prodigi). In the case of ostentum, the rarity of the phenomenon is astonishing. In the case of mon- strum, the order of nature is destroyed. In case of portentum, its final result is postponed. By prodigium is meant the occurrence of damage. (transl. DL)
The author of this collection gave us a unique compilation of those vari- ants that are independent of the rest of the known grammatical tradition.

\footnotetext{
${ }^{48}$ Charisius, Artis grammaticae libri V, C. BARwick (ed.) [Bibliotheca Scriptorum Graecorum et Romanorum Teubneriana], Leipzig 1964, pp. 388-389.

${ }^{49}$ A. Garcea, 'Grammar', [in:] S. McGill, E.J. Watts (eds.), A Companion to Late Antique Literature, New York 2018, pp. 461-462.

${ }^{50}$ Grammatici Latini, vol. 7, H. KeIL (ed.) [Bibliotheca Scriptorum Graecorum et Romanorum Teubneriana], Leipzig 1880.

${ }^{51}$ Revision of text based on: Charisius, Artis grammaticae libri V (cit. n. 48).
} 
The etymological tradition is almost imperceptible in this definition (except for portentum and porro). He associated with ostentum phenomena which in the normal course of things do not occur in nature or occur rarely. He gave only examples of optical phenomena, not interpreting them as predictive signs (although this is how they would be interpreted by most of the ancient sources). In the case of portentum, he did not indicate any specific referent, but linked it to a 'divinatory' context. Monstrum is simply an abomination of nature. We are presented with an interesting situation with prodigium, because the author mistook prodigium for prodigus.

The ancient definitions of the terms discussed above are a valuable testimony to the work methods of the ancient Grammarians. However, the value of their way of explaining the meaning of the terms prodigium, portentum, ostentum, and monstrum is questionable. I do not evaluate the correctness of the derived etymologies, but determining the meaning of these terms by means of the meaning of verbs from which they may be derived is a construct created by and (rather only) for Grammarians - displaying a typical product of their practice. The same is true for the other types of definitions. In the works of the Grammarians we can see an accumulation of material taken over from their predecessors. Not once did this process take the form of 'glossing' their works by adding more content, even though in this way the passus often lost its internal cohesion. Mutually contradictory attempts to assign these notions to the favorable or unfavorable phenomena, referring to the future or present, to natural phenomena, deformed bodies, static or ephemeral objects, all this demonstrates a desire to systematise the world for the purposes of research discourse, and in the case of some later treatises, it is also connected with an attempt to preserve correctness in a more and more barbaric Latin.

The legacy of the Grammarians should be treated as a secondary context, for relying on it can lead to the wrong conclusions. On the basis of the material analysed for the purpose of constructing the table, I can only point to a fairly high degree of correspondence between the definitions of monstrum (monstrum as something contra naturam) and the examples relating to 
mythological creatures and deformed human and animal beings. Moreover, if we rely only on the definitions themselves, we can get the impression that this is a complete set of basic terms describing 'signs from gods.' In this way, one loses sight of the usages of the term omen, which appears more than $600^{52}$ times in the sources (slightly less than monstrum), and often interchangeably with the four terms in question.

${ }^{52} 614$ attestations: Livius (27): Liv. I 7.12; Liv. I 55.4; Liv. V 18.3; Liv. V 21.16; Liv. V 34.8; Liv. V 34.9; Liv. V 55.2; Liv. VI 39.8; Liv. IX 14.8; Liv. IX 38.15; Liv. X 11.3; Liv. XXI 29.4; Liv. XXI 63.14; Liv. XXII 3.12; Liv. XXII 37.5; Liv. XXII 37.12; Liv. XXII 39.6; Liv. XXIII 13.4; Liv. XXVIII 41.13; Liv. XXIX 10.8; Liv. XXIX 27.13; Liv. XXX 12.14; Liv. XXXI 45.15; Liv. XXXII 25.2; Liv. XXXVIII 18.10; Liv. XLI 18.14; Liv. XLV 1.4; Periochae (3): Per. V; Per. XLIX; Per. XCLII; Velleius Paterculus (1): Vel. II 46; Suetonius (13): Suet. Iul. 59.1; Suet. Aug. 57.2; Suet. Aug. 83.1; Suet. Aug. 92.1; Suet. Aug. 94.11; Suet. Aug. 97.3; Suet. Aug. 98.2; Suet. Tib. 14.2; Suet. Gai. 8.1; Suet. Claud. 27.2; Suet. Ner. 46.1; Suet. Gal. 9.2; Suet. Vit. 8.2; Tacitus (22): Tac. Ann. I 28; Tac. Ann. I 35; Tac. Ann. II 13; Tac. Ann. II 14; Tac. Ann. IV 64; Tac. Ann. V 4; Tac. Ann. VI 37; Tac. Ann. XI 21; Tac. Ann. XV 7; Tac. Ann. XV 8; Tac. Ann. XV 74; Tac. Ann. XVI 35; Tac. Hist. I 6; Tac. Hist. I 62; Tac. Hist. I 86; Tac. Hist. II 1; Tac. Hist. II 78; Tac. Hist. II 91; Tac. Hist. III 56; Tac. Hist. IV 24; Tac. Hist. IV 83; Curtius Rufus (10): Curt. Ruf. III 6; Curt. Ruf. III 18; Curt. Ruf. IV 5; Curt. Ruf. IV 6; Curt. Ruf. IV 13; Curt. Ruf. V 4; Curt. Ruf. V 15; Curt. Ruf. VI 4; Curt. Ruf. X 20; Florus (3): Flor. Epit. I 6.8; Flor. Epit. I 22.40; Flor. Epit. II 26.15; Justinus (6): Just. Ep. XII 16.5; Just. Ep. XII 16.6; Just. Ep. XVIII 2.9; Just. Ep. XVIII 5.3; Just. Ep. XX 2.14; Just. Ep. XXVI 2.4; SHA (33): SHA. Hadr. 3.5; SHA. Ant. P. 3.1; SHA. Ant. P. 3.3; SHA. M. Aur. 4.3; SHA. Pert. 5.7; SHA. Pert. 14.4; SHA. Did. 7.1; SHA. Sev. 1.7; SHA. Sev. 7.9; SHA. Sev. 22.4; SHA. Sev. 22.5; SHA. C. Alb. 5.7; SHA. C. Alb. 5.8; SHA. C. Alb. 5.9; SHA. C. Alb. 5.10; SHA. Get. 3.5; SHA. Get. 3.7; SHA. Macr. 6.7; SHA. Diad. 1.2; SHA. Diad. 3.4; SHA. Diad. 5.6; SHA. Elag. 7.4; SHA. Alex. 13.1; SHA. Alex. 60.3; SHA. Max. 30.1; SHA. Max. 31.1; SHA. Max. et Balb. 5.4; SHA. Aur. 5.3; SHA. Tac. 17.1; SHA. Tac. 17.4; SHA. Prob. 7.5; SHA. Carin. 14.1; Eutropius (1): Eutr. VI 18; De viris illustribus (1): De vir. 31.1; Ammianus Marcellinus (15): Amm. XVI 11.1; Amm. XIX 10.3; Amm. XXI 2.2; Amm. XXI 10.2; Amm. XXI 15.2; Amm. XXII 1.2; Amm. XXII 12.7; Amm. XXIII 1.5; Amm. XXIII 3.7; Amm. XXIII 5.6; Amm. XXIII 5.8; Amm. XXIII 5.19; Amm. XXVII 6.12; Amm. XXVIII 4.8; Amm. XXX 5.17; Iordanes (1): Ior. HR. 198; Lucilius (1): Lucil. Sat. XXX frg. 1125-6; Vergilius (23): Verg. Aen. I 346; Verg. Aen. II 178; Verg. Aen. II 182; Verg. Aen. II 190; Verg. Aen. II 691; Verg. Aen. III 36; Verg. Aen. III 361; Verg. Aen. III 407; Verg. Aen. III 537; Verg. Aen. IV 662; Verg. Aen. V 524; Verg. Aen. V 530; Verg. Aen. VII 146; Verg. Aen. VII 174; Verg. Aen. VII 583; Verg. Aen. IX 21; Verg. Aen. X 250; Verg. Aen. X 311; Verg. Aen. XI 589; Verg. Aen. XII 72; Verg. Aen. XII 854; Verg. Georg. III 456; Verg. Georg. IV 386; Horatius (3): Hor. Carm. III 11.51; Hor. Carm. III 27.1; Hor. Carm. IV 5.13; Tibullus (1): Tib. I 3.12; Tib. I 3.17; Tib. II 5.82; Catullus (1): Cat. LXI 166; Propertius (11): Prop. El. II 3.24; Prop. El. II 28.38; Prop. El. III 4.9; Prop. El. III 20.24; Prop. El. IV 1.35; Prop. El. IV 1.41; Prop. El. IV 1.68; Prop. El. IV 3.13; Prop. El. IV 4.23; Prop. El. IV 6.23; Prop. El. IV 10.46; Ovidius (48): Ovid. Met. II 597; Ovid. Met. V 550; Ovid. Met. VI 448; Ovid. Met. VII 621; Ovid. Met. IX 


\section{Conclusions}

I have no doubt that future generations of researchers will attempt to establish the meaning of prodigium, portentum, ostentum, and monstrum. However, as I have demonstrated in the table, even if someone would like to shift a part of the attestations between the 'divinatory' and 'various' contexts, this would not change the fact that half of the attestations are not related to 'divinatory', and this circumstance limits the possibility of creating an 'ideal' definition - all the more so as there is a tendency to think of these terms essentially in the category of 'signs of gods', thereby marginalising other contexts. In the light of my conclusions, this is particularly evident from the Oxford Latin Dictionary's entry for monstrum. The 'divinatory' interpretation can be found there in the first place (OLD, s.v. monstrum: 'An unnatural thing or event regarded as an omen, a portent, prodigy, sign'), while only $21.19 \%$ of the attestations I have collected concern this context. The order may have to be reversed.

572; Ovid. Met. IX 595; Ovid. Met. IX 767; Ovid. Met. IX 785; Ovid. Met. X 5; Ovid. Met. X 278; Ovid. Met. X 452; Ovid. Met. XI 719; Ovid. Met. XII 218; Ovid. Met. XIV 272; Ovid. Met. XV 791; Ovid. Fasti I 59; Ovid. Fasti I 178; Ovid. Fasti I 187; Ovid. Fasti I 221; Ovid. Fasti I 616; Ovid. Fasti II 202; Ovid. Fasti II 204; Ovid. Fasti II 549; Ovid. Fasti III 396; Ovid. Fasti IV 356; Ovid. Fasti IV 833; Ovid. Trist. II 6; Ovid. Am. I 12.3; Ovid. Am. I 14.41; Ovid. Am. II 14.42; Ovid. Am. II 17.11; Ovid. Am. III 12.2; Ovid. Ex P. II 1.35; Ovid. Ex P. II 1.68; Ovid. Ex P. II 5.1; Ovid. Ex P. III 4.98; Ovid. Ex P. IV 9.54; Ovid. Ex P. IV 11.21; Ovid. Ib. 101; Ovid. Ars am. I 212; Ovid. Her. VII 65; Ovid. Her. VIII 116; Ovid. Her. IX 40; Ovid. Her. XIII 49; Ovid. Her. XIII 135; Ovid. Her. XVII 159; Ovid. Her. XIX 201; Ovid. Her. XX 99; Phaedrus (1): Phaedr. 3.18; Juvenalis (1): Juv. Sat. IV 125; Lucanus (12): Luc. BC. I 112; Luc. BC. I 637; Luc. BC. II 6; Luc. BC. III 101; Luc. BC. III 212; Luc. BC. IV 551; Luc. BC. IV 664; Luc. BC. VI 397; Luc. BC. VII 22; Luc. $B C$. VII 184; Luc. BC. VII 341; Luc. BC. VIII 585; Calpurnius Siculus (1): Calp. Buc. III 97; Statius (41): Stat. Silv. I 2.230; Stat. Silv. II 2.79; Stat. Silv. III 1.149; Stat. Silv. III 2.52; Stat. Silv. IV 8.22; Stat. Silv. V 2.165; Stat. Ach. I 147; Stat. Ach. I 683; Stat. Th. I 180; Stat. Th. I 490; Stat. Th. I 504; Stat. Th. II 196; Stat. Th. II 263; Stat. Th. II 692; Stat. Th. III 71; Stat. Th. III 459; Stat. Th. III 473; Stat. Th. III 505; Stat. Th. III 516; Stat. Th. III 632; Stat. Th. IV 330; Stat. Th. V 319; Stat. Th. VI 222; Stat. Th. VI 342; Stat. Th. VI 66; Stat. Th. VI 636; Stat. Th. VI 923; Stat. Th. VI 934; Stat. Th. VI 936; Stat. Th. VII 258; Stat. Th. VII 586; Stat. Th. VII 663; Stat. Th. VIII 69; Stat. Th. VIII 708; Stat. Th. IX 630; Stat. Th. IX 887; Stat. Th. X 486; Stat. Th. XI 139; Stat. Th. XI 669; Stat. Th. XI 702; Stat. Th. XI 705; Valerius Flaccus (8): Val. Flac. Arg. I 232; Val. Flac. Arg. I 245; Val. Flac. Arg. I 309; Val. Flac. Arg. III 121; Val. Flac. Arg. V 95; Val. Flac. Arg. V 211; Val. Flac. Arg. VI 70; Val. Flac. Arg. VI 730; Martialis (1): Mart. Ep. XII 98.5; Silius Italicus (22): Sil. 
While it is most justified to say that the terms in question are synonymous, I think we should speak of their synonimic connotation (all of them, although not always, could be associated with signs from the gods) rather than their referents (all terms refer to the same phenomenon). I suspect that a more thorough examination of all the attestations belonging to the "divinatory' context, which goes far beyond the scope of this article, would allow for a deeper and more nuanced exploration of the connotational meaning.

Pun. I 342; Sil. Pun. II 54; Sil. Pun. II 379; Sil. Pun. II 411; Sil. Pun. III 12; Sil. Pun. III 133; Sil. Pun. III 217; Sil. Pun. IV 127; Sil. Pun. IV 131; Sil. Pun. IV 709; Sil. Pun. VII 48; Sil. Pun. IX 4; Sil. Pun. IX 179; Sil. Pun. IX 253; Sil. Pun. IX 262; Sil. Pun. X 614; Sil. Pun. XIII 114; Sil. Pun. XIII 510; Sil. Pun. XV 442; Sil. Pun. XVI 124; Sil. Pun. XVI 260; Sil. Pun. XVI 271; Ausonius (2): Aus. Ep. 27.120; Aus. Grat. 11; Avienus (1): Av. Ar. 3; Avianus (1): Avian. Fab. XXIII 7; Claudian (23): Claud. De rap. I 266; Claud. De rap. II 364; Claud. De rap. III 132; Claud. De cons. Stil. II 293; Claud. De bello Goth. 26.239; Claud. De IV cons. Hon. Aug. 196; Claud. De IV cons. Hon. Aug. 614; Claud. De VI cons. Hon. Aug. 14; Claud. De VI cons. Hon. Aug. 24; Claud. In Eutr. I 22; Claud. In Eutr. I 125; Claud. In Eutr. I 491; Claud. In Eutr. II. praef. 11; Claud. In Eutr. II 8; Claud. In Eutr. II 36; Claud. In Eutr. II 285; Claud. In Eutr. II 487; Claud. In Ruf. II 96; Claud. In Ruf. II 335; Claud. De bello Gild. 467; Claud. Carm. min. XXX (XXXIX) 94; Claud. Carm. min. XLI (XLII) 15; Claud. In Prob. et Olyb. 208; Luxorius (1): Lux. 39.3; Dracontius (5): Drac. Epith. I.115; Drac. Rapt. H. 474; Drac. Deliber. 209; Drac. Deliber. 230; Drac. Med. 188; Plautus (9): Pl. Amph. 272; Pl. Ep. 396; Pl. Mer. 274 Pl. Pers. 625; Pl. Pers. 736; Pl. Cas. 411; Pl. Cas. 510; Pl. Ep. 397; Pl. Most. 464; Terentius (1): Ter. Andr. 200; Afranius (1): Non. 681; Seneca Minor (tragedies) (7): Sen. Phaed. 408; Sen. Phaed. 623; Sen. Ag. 939; Sen. Oed. 359; Sen. Oed. 855; Sen. Troad. 488; Sen. Her. f. 688; Pseudo-Seneca (2): Ps.-Sen. Oct. 80; Ps.-Sen. Oct. 704; Valerius Maximus (16): Val. Max. I 5.1; Val. Max. I 5.2; Val. Max. I 5.3; Val. Max. I 5.4; Val. Max. I 5.9; Val. Max. I 6.10; Val. Max. I 5. init.; Val. Max. I 5.4; Val. Max. I 5.5; Val. Max. I 5.6; Val. Max. I 5.7; Val. Max. I 5. ext. 2; Val. Max. II 4.5; Val. Max. III 2.3; Val. Max. IV 7.7; Val. Max. VII 2.5; Petronius (4): Petr. Sat. 103; Petr. Sat. 107; Petr. Sat. 122.178; Petr. Sat. 123.183; Apuleius (6): Apul. Met. II 26; Apul. Ap. 92.9; Apul. Deo Soc. 19; Apul. Deo Soc. 20; Fulgentius (1): Fulg. Myth. I 20; Cicero (42): Cic. In Verr. II 1.99; Cic. In Verr. II 2.18; Cic. In Verr. II 2.19; Cic. Pro Flacco 104; Cic. Pro Scauro 30; Cic. De leg. agr. II 92; Cic. Pro Clu. 14; Cic. Pro Sest. 71; Cic. In Pis. 31; Cic. Pro Rosc. 139; Cic. De harusp. 42; Cic. Phil. III 35; Cic. Phil. IV 10; Cic. Phil. VII 11; Cic. Phil. IX 9; Cic. Phil. XI 11; Cic. Phil. XII 14; Cic. Phil. XII 19; Cic. Phil. XIII 7; Cic. Phil. XIII 41; Cic. Phil. XIV 26; Cic. De dom. 140; Cic. Cat. I 33; Cic. Pro Planc. 26; Cic. Pro Mur. 38; Cic. Pro Mur. 88; Cic. Fam. III 12; Cic. Fam. XII 6.2; Cic. Brut. I 10.5; Cic. Brut. I 12.1; Cic. $D D$. I 29; Cic. DD. I 102; Cic. DD. I 103; Cic. DD. I 104; Cic. DD. I 106; Cic. DD. II 26; Cic. DD. II 83; Cic. DD. II 84; Cic. DD. II 149; Seneca Maior (9): Sen. Contr. I 8.2; Sen. Contr. I 8.15; Sen. Contr. II 1.27; Sen. Contr. IV 1; Sen. Contr. IV 2; Sen. Contr. VII 1.4; Sen. Contr. VII 1.8; Sen. Contr. X 4.8; Sen. Contr. X 4.16; Seneca Minor (2): Sen. Ad Marc. 3.3; Sen. Ad Marc. 9.4; Quintilian (3): Quint. Inst. or. III 6.30; Quint. Inst. or. IV 2.122; Quint. Inst. or. V 7.35; Pseudo-Quin- 
Although the definitions of the ancient Grammarians are valuable material, I believe that we should not start with them in order to study the aforementioned words. Not only do they impose choices which, as it turns out after analysing the non-grammatical material, do not really have to be made, but they also impose the idea that prodigium, portentum, ostentum, and monstrum are terms belonging to the 'divinatory' context. This is true - but only in $50 \%$ of the cases.

tilian (3): Ps.-Quint. D. Maior. 1.13; Ps.-Quint. D. Min. 315.23; Ps.-Quint. D. Min. 317.14; Plinius Minor (2): Plin. Ep. IV 15.4; Plin. Paneg. 92; Panegyrici latini (5): Paneg. Geneth. Max. Aug. III 10; Paneg. Geneth. Max. Aug. III 12; Paneg. Const. Aug. XII 21; Paneg. Grat. De cons. suo Iul. III 32; Pomponius Mela (1): Pomp. M. Geogr. II 49 [56]; Seneca Minor (QN) (2): Sen. $Q N$. VII 17.3; Sen. QN. VI 32.6; Plinius Secundus (7): Plin. HN. I 11.18; Plin. HN. VII 69; Plin. $H N$. VIII 84; Plin. HN. IX 94; Plin. HN. IX 121; Plin. HN. XV 83; Plin. HN. XVI 133; Solinus (3): Sol. I 66; Sol. IX 17; Sol. XXXII 19; Firmicus Maternus (Math.) (1): Firm. Math. VI 30.10; Varro (LL) (6): Var. $L L$. V 116; Var. $L L$. V 159; Var. $L L$. VI 76; Var. $L L$. VII 97; Var. $L L$. VII 96; Aulus Gellius (4): Aul. Gel. NA. I 22.21; Aul. Gel. NA. IV 9.5; Aul. Gel. NA. IV 9.11; Aul. Gel. NA. XVIII 7.8; Festus (7): Fest. 218; Fest. 282; Fest. 312; Fest. 314; Fest. 342; Fest. 364; Fest. 410; Macrobius (Saturnalia) (5): Macr. Sat. I 6.10; Macr. Sat. V 14.13; Macr. Sat. V 13.30; Macr. Sat. I 12.37; Macr. Sat. I 3.13; Servius (82): Serv. Aen. I 120; Serv. Aen. I 270; Serv. Aen. I 346; Serv. Aen. I 443; Serv. Aen. I 650; Serv. Aen. I 653; Serv. Aen. I 704; Serv. Aen. II 182; Serv. Aen. II 691; Serv. Aen. II 693; Serv. Aen. III 176; Serv. Aen. III 178; Serv. Aen. III 246; Serv. Aen. III 262; Serv. Aen. III 361; Serv. Aen. III 407; Serv. Aen. III 537; Serv. Aen. III 538; Serv. Aen. III 544; Serv. Aen. III 718; Serv. Aen. IV 57; Serv. Aen. IV 73; Serv. Aen. IV 127; Serv. Aen. IV 161; Serv. Aen. IV 167; Serv. Aen. IV 340; Serv. Aen. IV 384; Serv. Aen. IV 453; Serv. Aen. IV 455; Serv. Aen. IV 462; Serv. Aen. IV 467; Serv. Aen. IV 572; Serv. Aen. IV 644; Serv. Aen. IV 661; Serv. Aen. IV 662; Serv. Aen. V 5; Serv. Aen. V 7; Serv. Aen. V 71; Serv. Aen. V 85; Serv. Aen. V 530; Serv. Aen. V 635; Serv. Aen. VI 248; Serv. Aen. VI 862; Serv. Aen. VII 147; Serv. Aen. VII 583; Serv. Aen. VIII 102; Serv. Aen. VIII 110; Serv. Aen. VIII 139; Serv. Aen. VIII 233; Serv. Aen. VIII 270; Serv. Aen. VIII 302; Serv. Aen. VIII 345; Serv. Aen. VIII 363; Serv. Aen. VIII 484; Serv. Aen. VIII 526; Serv. Aen. VIII 533; Serv. Aen. VIII 709; Serv. Aen. IX 21; Serv. Aen. IX 52; Serv. Aen. IX 253; Serv. Aen. X 250; Serv. Aen. X 311; Serv. Aen. XI 235; Serv. Aen. XI 347; Serv. Aen. XI 378; Serv. Aen. XI 476; Serv. Aen. XI 589; Serv. Aen. XII 17; Serv. Aen. XII 74; Serv. Aen. XII 638; Serv. Aen. XII 854; Serv. Aen. XII 864; Martianus Capella (7): Mart. Cap. I 10; Mart. Cap. I 30; Mart. Cap. I 31; Mart. Cap. II 124; Mart. Cap. II 149; Mart. Cap. II 193; Mart. Cap. V 516; Nonius Marcellus (11): Non. 212; Non. 540; Non. 566; Non. 566; Non. 567; Non. 666; Non. 693694; Isidorus (Etym.) (1): Isid. Etym. XII 7.38; Paulus (10): Fest. Paul. 6; Fest. Paul. 31; Fest. Paul. 55; Fest. Paul. 79; Fest. Paul. 85; Fest. Paul. 108; Fest. Paul. 110; Fest. Paul. 283; Fest. Paul. 411; Fest. Paul. 213; Tertullianus (4): Tert. Ad Marc. III 5.3; Tert. De anim. 24.10; Tert. De pall. 1.2; Tert. De test. an. 5.2; Arnobius (6): Arn. Adv. nat. I 16.6; Arn. Adv. nat. I 35.1; Arn. Adv. nat. IV 5.5; Arn. Adv. nat. VI 7.4; Arn. Adv. nat. VII 19.4; Arn. Adv. nat. VII 20.1. 


\section{Contents of the tABle}

Livius: Prodigium (div.): Liv. I 20.7; Liv. I 31.2; Liv. I 31.4; Liv. I 34.9; Liv. I 39.1; Liv. I 45.5; Liv. I 45.7; Liv. I 55.5; Liv. I 56.5; Liv. II 42.10; Liv. III 10.6; Liv. III 29.9; Liv. IV 21.5; Liv. V 14.3; Liv. V 15.1; Liv. V 15.3; Liv. V 16.1; Liv. V 17.1; Liv. V 18.12; Liv. V 23.1; Liv. V 52.9; Liv. VII 6.7; Liv. VII 26.5; Liv. VII 28.7; Liv. VIII 18.11; Liv. X 23.1; Liv. X 31.8; Liv. XXI 23.9; Liv. XXI 46.2; Liv. XXI 62.1; Liv. XXI 62.6; Liv. XXII 1.8; Liv. XXII 1.13; Liv. XXII 1.15; Liv. XXII 3.14; Liv. XXII 9.8; Liv. XXII 36.7; Liv. XXII 36.8; Liv. XXII 57.2; Liv. XXII 57.4; Liv. XXIII 31.15; Liv. XXIII 36.10; Liv. XXIII 39.6; Liv. XXIV 10.6; Liv. XXIV 10.13; Liv. XXIV 44.7; Liv. XXV 7.9; Liv. XXV 16.2; Liv. XXV 16.4; Liv. XXV 17.3; Liv. XXVI 19.7; Liv. XXVI 23.4; Liv. XXVI 23.6; Liv. XXVI 45.9; Liv. XXVII 4.11; Liv. XXVII 4.15; Liv. XXVII 11.2; Liv. XXVII 11.6; Liv. XXVII 23.2; Liv. XXVII 23.4; Liv. XXVII 25.8; Liv. XXVII 27.2; Liv. XXVII 27.4; Liv. XXVII 27.6; Liv. XXVII 27.8; Liv. XXVIII 11.2; Liv. XXVIII 11.5; Liv. XXVIII 11.6; Liv. XXIX 14.3; Liv. XXX 2.9; Liv. XXX 2.13; Liv. XXX 38.8; Liv. XXX 38.9; Liv. XXXI 12.5; Liv. XXXI 12.9; Liv. XXXI 29.11; Liv. XXXII 1.13; Liv. XXXII 1.14; Liv. XXXII 9.1; Liv. XXXII 9.4; Liv. XXXII 29.1; Liv. XXXIII 26.6; Liv. XXXIII 26.9; Liv. XXXIV 45.6; Liv. XXXIV 45.7; Liv. XXXV 9.5; Liv. XXXV 21.3; Liv. XXXV 21.5; Liv. XXXVI 37.4; Liv. XXXVI 37.6; Liv. XXXVII 3.1; Liv. XXXIX 22.5; Liv. XXXIX 46.5; Liv. XXXIX 56.6; Liv. XL 2.3; Liv. XL 2.4; Liv. XL 19.1; Liv. XL 19.4; Liv. XL 37.2; Liv. XL 45.4; Liv. XL 59.6; Liv. XL 59.8; Liv. XLI 9.5; Liv. XLI 9.7; Liv. XLI 13.1; Liv. XLI 13.3; Liv. XLI 15.3; Liv. XLI 16.6; Liv. XLII 2.3; Liv. XLII 2.6; Liv. XLII 2.7; Liv. XLII 20.2; Liv. XLII 20.4; Liv. XLII 20.6; Liv. XLIII 13.2; Liv. XLIII 13.3; Liv. XLIII 13.5; Liv. XLIII 13.6; Liv. XLIII 13.7; Liv. XLIV 37.8; Liv. XLIV 37.9; Liv. XLV 16.5; Liv. XLV 16.6; Portentum (div.): Liv. I 56.4; Liv. III 5.14; Liv. V 15.6; Liv. X 47.6; Liv. XXVIII 27.16; Liv. XXX 12.9; Liv. XLIV 37; Portentum(var.): Liv. XXVIII 27.16; Ostentum (div.): Liv. XXVI 6.14; Monstrum (var.): Liv. IV 15.8;

Periochae: Prodigium (div.): Per. XIV; Per. XXXII; Per. XXXV;

Sallustius: Prodigium (div.): Sall. Cat. 30.2; Sall. Cat. 47.2; Portentum (div.): Sall. Cat. 30.2;

Suetonius: Prodigium (div.): Suet. Iul. 81.1; Suet. Aug. 94.3; Suet. Gai. 57.1; Suet. Gai. 57.4; Suet. Vesp. 23.4; Portentum (div.): Suet. Ner. 46.1; Portentum (var.): Suet. Claud. 3.2; Ostentum (div.): Suet. Iul. 32.1; Suet. Iul. 32.1; Suet. Iul. 77.1 Suet. Aug. 92.2; Suet. Aug. 94.2; Suet. Aug. 94.5; Suet. Aug. 94.11; Suet. Aug. 97.1; Suet. Tib. 14.1; Suet. Tib. 19.1; Suet. Tib. 72.1; Suet. Gai. 57.2; Suet. Claud. 29.3; Suet. Ner. 36.1; Suet. Gal. 4.2; Suet. Vit. 9.1; Suet. Vesp. 5.1; Suet. Dom. 23.2; Monstrum (div.): Suet. Gal. 18.1; Monstrum (var.): Suet. Gai. 22.1;

Tacitus: Prodigium (div.): Tac. Ann. XII 43; Tac. Ann. XII 43; Tac. Ann. XII 64; Tac. Ann. XIII 58; Tac. Ann. XIV 12; Tac. Ann. XV 7; Tac. Ann. XV 47; Tac. Hist. 
I 3;Tac. Hist. I 86; Tac. Hist. I 86; Tac. Hist. IV 26; Tac. Hist. V 13; Prodigium (var.): Tac. Hist. IV 58; Ostentum (div.): Tac. Ann. XII 64; Tac. Hist. I 10; Ostentum (var.): Tac. Ann. XV 64; Tac. Hist. III 56; Monstrum (var.): Tac. Ann. II 24;

Curtius Rufus: Monstrum (div.): Curt. Ruf. IX 10; Monstrum (var.): Curt. Ruf. IX 14 ;

Florus: Prodigium (div.): Flor. Epit. II 13.46; Prodigium (var.): Flor. Epit. I 4.3; Flor. Epit. I 39.4; Flor. Epit. II 6.6; Portentum (var.): Flor. Epit. II 13.60; Monstrum (div.): Flor. Epit. I 1.9; Monstrum (var.): Flor. Epit. I 4.8; Flor. Epit. I 18.5; Flor. Epit. I 18.20; Flor. Epit. II 21.3;

Justinus: Prodigium (div.): Just. Epit. XII 16.4; Just. Epit. XV 4.18; Just. Epit. XXII 6.2; Just. Epit. XXX 4.4; Just. Epit. XXXVI 2.8; Just. Epit. XL 2.1; Portentum (div.): Just. Epit. XVII 1.3; Just. Epit. XXII 6.1; Just. Epit. XXXIII 1.7; Ostentum (div.): Just. Epit. X 1.6; Just. Epit. XVII 1.4; Just. Epit. XXIII 4.11; Just. Epit. XXXVII 2.1; Monstrum (var.): Just. Epit. IV 1.13; Just. Epit. XVIII 1.6;

Aurelius Victor: Prodigium (div.): Aur. Caes. 5.17; Aur. Caes. 26.3; Aur. Caes. 28.3; Portentum (div.): Aur. Caes. 28.3; Ostentum (div.): Aur. Caes. 41.14;

SHA: Prodigium (div.): SHA. Com. 16.1; SHA. Com. 16.6; SHA. Car. 11.1; Prodigium (var.): SHA. Aur. 1.5; SHA. Tac. 6.4; Ostentum (div.): SHA. Hadr. 23.4; Monstrum (div.): SHA. Aur. 21.4; Monstrum (var.): SHA. El. 26.8;

Ammianus Marcellinus: Prodigium (div.): Amm. XVIII 3.1; Amm. XXX 5.15; Portentum (div.): Amm. XIX 12.20; Amm. XXIII 2.7; Amm. XXVII 3.1; Amm. XXI 1.1; Ostentum (div.): Amm. XXIII 3.6; Monstrum (div.): Amm. XIX 12.19; Monstrum (var.): Amm. XXII 15.14; Amm. XXII 15.20;

Obsequens: Prodigium (div.): Obsq. 23; Obsq. 28; Obsq. 29; Obsq. 54; Obsq. 56; Obsq. 58; Obsq. 60; Obsq. 61; Obsq. 64; Obsq. 65; Obsq. 69; Obsq. 70;

Orosius: Prodigium (div.): Oros. II 12.2; Oros. III 5.1; Oros. IV 4.1; Oros. IV 5.1; Oros. IV 13.12; Oros. IV 15.1; Oros. IV 21.7; Oros. V 4.8; Oros. V 4.19; Oros. V 12.1; Oros. V 15.20; Oros. V 18.3; Oros. V 18.9; Oros. V 20.7; Prodigium (var.): Oros. I 8.3; Oros. I 13.2; Monstrum (div.): Oros. IV 1.16; Oros. V 6.2; Monstrum (var.): Oros. I 2.31;

Gregorius Florentius (Historiae): Prodigium (div.): Greg. Hist. II 34; Greg. Hist. IV 31; Greg. Hist. IV 31; Greg. Hist. IV 34; Greg. Hist. V 23; Greg. Hist. V 33; Greg. Hist. V 34; Greg. Hist. V 41; Greg. Hist. VI 14; Greg. Hist. VI 33; Greg. Hist. VI 44; Greg. Hist. VII 1; Greg. Hist. IX 5; Prodigium (var.): Greg. Hist. I 20; Greg. Hist. IX 6; Greg. Hist. X 25; Portentum (div.): Greg. Hist. VI 14;

Iordanes, Historia Romana: Monstrum (div.): Ior. HR. 106; Monstrum (var.): Ior. HR. 122; Ior. HR. 163; Ior. HR. 169; 
Hieronymi chronicon: Portentum (div.): Ch. Hier. 44 BCE; Ch. Hier. 96 CE;

Isidorus Hispalensis, Historia de regibus Gothorum, Vandalorum et Suevorum: Prodigium (div.): Hist. 26; Ostentum (div.): Hist. 24; Ostentum (var.): Hist. 32;

Hydatii Episcopi chronicon: Prodigium (div.): Hyd. 45.1 (= $462 \mathrm{CE}$ ); Hyd. 46.2 (= $468 \mathrm{CE}$ ); Portentum (div.): Hyd. 45.1 (= $462 \mathrm{CE})$; Hyd. 46.1 (= $467 \mathrm{CE})$; Ostentum (div.): Hyd. 46.2 (= $468 \mathrm{CE})$; Hyd. 41.18 (= $442 \mathrm{CE})$;

Chronicon Marcellini Comitis: Monstrum (var.): Ch. Marc. 399 CE;

Excerpta Latina Barbari: Prodigium (var.): p. 224 [ed. Frick];

Lucilius: Portentum (var.): Lucil. Sat. XXVI 6. frg. 723; Lucil. Sat. 15, frg. 520-3; Monstrum (var.): Lucil. Sat. 15, frg. 520-3;

Lucretius: Portentum (var.): Lucr. II 701; Lucr. IV 590; Lucr. V 37; Lucr. V 837; Lucr. V 845; Monstrum (var.): Lucr. IV 590; Lucr. V 845;

Vergilius: Prodigium (div.): Verg. Aen. III 366; Verg. Aen. V 639; Verg. Aen. VI 379; Prodigium (var.): Verg. Aen. VIII 295; Portentum (div.): Verg. Aen. VII 58; Verg. Aen. VIII 533; Portentum (var.): Verg. Aen. XI 271; Monstrum (div.): Verg. Aen. II 171; Verg. Aen. II 245; Verg. Aen. II 680; Verg. Aen. III 26; Verg. Aen. III 59; Verg. Aen. V 523; Verg. Aen. V 659; Verg. Aen. VII 81; Verg. Aen. VII 270; Verg. Aen. VIII 81; Verg. Aen. IX 120; Verg. Aen. IX 128; Verg. Aen. XII 246; Monstrum (var.): Verg. Aen. III 214; Verg. Aen. III 307; Verg. Aen. III 583; Verg. Aen. III 658; Verg. Aen. IV 181; Verg. Aen. V 849; Verg. Aen. VI 285; Verg. Aen. VI 729; Verg. Aen. VII 21; Verg. Aen. VII 328; Verg. Aen. VII 348; Verg. Aen. VII 376; Verg. Aen. VII 780; Verg. Aen. VIII 198; Verg. Aen. VIII 289; Verg. Aen. VIII 698; Verg. Aen. X 637; Verg. Aen. XII 874; Verg. Ec. VI 75; Verg. Georg. I 185; Verg. Georg. III 152; Verg. Georg. IV 554;

Horatius: Portentum (var.): Hor. Carm. I 22.13; Hor. Epist. II 2.209; Hor. Epist. II 1.11; Monstrum (var.): Hor. Carm. I 2.6; Hor. Carm. I 3.18; Hor. Carm. I 37.21; Hor. Carm. III 4.73; Hor. Carm. III 27.48; Hor. Carm. IV 4.63; Hor. Epod. 16.30;

Grattius: Monstrum (var.): Gratt. Cyn. 443;

Tibullus: Prodigium (div.): Tib. II 5.80;

Catullus: Monstrum (var.): Cat. LXIV 15; Cat. LXIV 101; Cat. LXVIII 113; Cat. CIV 4;

Propertius: Portentum (var.): Prop. El. III 6.27; Prop. El. III 22.28; Monstrum (var.): Prop. El. II 28.21; Prop. El. IV 4.41; Prop. El. IV 7.58;

Ovidius: Prodigium (div.): Ovid. Met. XI 411; Prodigium (var.): Ovid. Met. VI 321; Ovid. Met. XIII 917; Ovid. Fasti II 556; Ovid. Her. IX 91; Portentum (var.): Ovid. Am. II 16.23; Ostentum (var.): Ovid. Met. IV 565; Monstrum (div.): Ovid. Met. XV 571; Monstrum (var.): Ovid. Met. I 437; Ovid. Met. II 367; Ovid. Met. II 675; Ovid. Met. IV 488; Ovid. Met. IV 500; Ovid. Met. IV 591; Ovid. Met. IV 615; Ovid. 
Met. IV 745; Ovid. Met. V 216; Ovid. Met. V 241; Ovid. Met. V 459; Ovid. Met. VI 294; Ovid. Met. VIII 100; Ovid. Met. VIII 156; Ovid. Met. VIII 170; Ovid. Met. IX 667; Ovid. Met. IX 736; Ovid. Met. X 22; Ovid. Met. X 553; Ovid. Met. XI 211; Ovid. Met. XI 391; Ovid. Met. XII 175; Ovid. Met. XIII 912; Ovid. Met. XIV 60; Ovid. Met. XIV 412; Ovid. Met. XIV 414; Ovid. Met. XIV 567; Ovid. Met. XV 517; Ovid. Fasti I 554; Ovid. Fasti III 723; Ovid. Fasti III 799; Ovid. Fasti IV 304; Ovid. Fasti IV 500; Ovid. Fasti V 35; Ovid. Ex P. IV 10.25; Ovid. Ib. 373; Ovid. Ars am. II 217; Ovid. Ars am. III 311; Ovid. Her. IX 34;

Phaedrus: Ostentum (div.): Phaedr. 3.3; Monstrum (div.): Phaedr. 3.3;

Manilius: Portentum (var.): Man. Astr. IV 104; Monstrum (var.): Man. Astr. IV 662; Man. Astr. V 191; Man. Astr. V 567; Man. Astr. V 581; Man. Astr. V 618;

Germanicus: Monstrum (var.): Germ. Arat. 50; Germ. Arat. 358;

Juvenalis: Prodigium (var.): Juv. Sat. VI 84; Juv. Sat. IV 97; Portentum (var.): Juv. Sat. XV 2; Monstrum (div.): Juv. Sat. XIII 65; Monstrum (var.): Juv. Sat. II 122; Juv. Sat. II 143; Juv. Sat. IV 2; Juv. Sat. IV 45; Juv. Sat. IV 115; Juv. Sat. VI 286; Juv. Sat. VI 645; Juv. Sat.VI 647; Juv. Sat. IX 38; Juv. Sat. XIV 283; Juv. Sat. XV 121; Juv. Sat. XV 172;

Lucanus: Prodigium (div.): Luc. BC. I 525; Luc. BC. IX 475; Portentum (var.): Luc. BC. V 284; Luc. BC. VIII 414; Monstrum (div.): Luc. BC. I 563; Luc. BC. I 589; Luc. $B C$. VII 172; Luc. BC. VII 183; Monstrum (var.): Luc. BC. IV 245; Luc. BC. IV 251; Luc. $B C$. IV 610; Luc. $B C$. VI 436; Luc. $B C$. VI 635; Luc. $B C$. VII 464; Luc. $B C$. VII 783; Luc. BC. VIII 474; Luc. BC. VIII 541; Luc. BC. VIII 548; Luc. BC. VIII 613; Luc. $B C$. IX 637; Luc. BC. IX 645; Luc. BC. IX 663; Luc. BC. IX 666; Luc. BC. IX 855; Luc. $B C$. IX 910; Luc. $B C$. X 337; Luc. $B C$. X 474;

Calpurnius Siculus: Monstrum (var.): Calp. Buc. VII 64;

Statius: Prodigium (div.): Stat. Th. XI 454; Portentum (div.): Stat. Th. III 640; Stat. Th. III 512; Monstrum (div.): Stat. Th. I 395; Stat. Th. II 126; Stat. Th. III 510; Stat. Th. IV 406; Stat. Th. VII 402; Stat. Th. X 205; Stat. Th. XI 143; Monstrum (var.): Stat. Silv. I 2.39; Stat. Silv. III 1.48; Stat. Silv. III 2.36; Stat. Silv. V 3.280; Stat. Ach. I 662; Stat. Ach. I 890; Stat. Th. I 235; Stat. Th. I 459; Stat. Th. I 487; Stat. Th. I 562; Stat. Th. I 597; Stat. Th. I 615; Stat. Th. I 637; Stat. Th. I 648; Stat. Th. II 212; Stat. Th. III 224; Stat. Th. IV 157; Stat. Th. IV 395; Stat. Th. IV 533; Stat. Th. IV 639; Stat. Th. IV 834; Stat. Th. V 570; Stat. Th. VI 495; Stat. Th. VI 534; Stat. Th. VII 111; Stat. Th. VIII 66; Stat. Th. IX 11; Stat. Th. IX 102; Stat. Th. IX 300; Stat. Th. XI 420; Stat. Th. XI 578; Stat. Th. XII 236; Stat. Th. XII 422; Stat. Th. XII 554; Stat. Th. XII 575;

Valerius Flaccus: Prodigium (div.): Val. Flac. Arg. I 743; Prodigium (var.): Val. Flac. Arg. IV 430; Monstrum (div.): Val. Flac. Arg. III 356; Val. Flac. Arg. V 259; Val. Flac. Arg. V 329; Val. Flac. Arg. VI 6; Monstrum (var.): Val. Flac. Arg. I 33; 
Val. Flac. Arg. I 374; Val. Flac. Arg. I 849; Val. Flac. Arg. II 17; Val. Flac. Arg. I I 217; Val. Flac. Arg. II 248; Val. Flac. Arg. II 479; Val. Flac. Arg. II 489; Val. Flac. Arg. II 514; Val. Flac. Arg. III 29; Val. Flac. Arg. III 261; Val. Flac. Arg. III 512; Val. Flac. Arg. III 567; Val. Flac. Arg. III 610; Val. Flac. Arg. III 665; Val. Flac. Arg. IV 155; Val. Flac. Arg. IV 188; Val. Flac. Arg. IV 370; Val. Flac. Arg. IV 456; Val. Flac. Arg. IV 462; Val. Flac. Arg. IV 506; Val. Flac. Arg. IV 605; Val. Flac. Arg. IV 750; Val. Flac. Arg. V 482; Val. Flac. Arg. V 657; Val. Flac. Arg. VI 45; Val. Flac. Arg. VI 437; Val. Flac. Arg. VI 470; Val. Flac. Arg. VII 267; Val. Flac. Arg. VII 345; Val. Flac. Arg. VII 420; Val. Flac. Arg. VII 522; Val. Flac. Arg. VII 536;

Martialis: Portentum (div.): Mart. Ep. XI 102.8; Monstrum (var.): Mart. Ep. I 90.9; Mart. Ep. IV 57.5; Mart. Ep. IV 63.3; Mart. Ep. V 65.9; Mart. Ep. VII 38.3; Mart. Ep. VII 87.10; Mart. Ep. IX 7(8).6; Mart. Ep. IX 65.4; Mart. Ep. X 4.2; Mart. Ep. XIV 182; Mart. Spect. 32.9;

Silius Italicus: Prodigium (div.): Sil. Pun. V 76; Sil. Pun. XIII 132; Sil. Pun. XVI 128; Portentum (div.): Sil. Pun. XVI 125; Monstrum (div.): Sil. Pun. III 198; Sil. Pun. IX 1; Sil. Pun. XVI 133; Sil. Pun. XVII 550; Sil. Pun. XVII 595; Monstrum (var.): Sil. Pun. I 278; Sil. Pun. II 158; Sil. Pun. II 553; Sil. Pun. II 650; Sil. Pun. VI 151; Sil. Pun. VI 193; Sil. Pun. VI 204; Sil. Pun. VI 246; Sil. Pun. VI 262; Sil. Pun. VI 583; Sil. Pun. VI 629; Sil. Pun. IX 571; Sil. Pun. IX 599; Sil. Pun. IX 628; Sil. Pun. X 61; Sil. Pun. X 101; Sil. Pun. X 158; Sil. Pun. XIII 201; Sil. Pun. XIII 579;

Ausonius: Portentum (var.): Aus. Ephem. 8.12; Aus. Tech. 10.25; Monstrum (var.): Aus. Ep. 14.40; Aus. Ep. 27.67; Aus. Caes. 24.100; Aus. Cent. Nupt. 8.108; Aus. Epigr. 76.5;

Avienus, Aratea: Monstrum (var.): Av. Ar. 144; Av. Ar. 251; Av. Ar. 778; Av. Ar. 1143; Av. Ar. 1152; Av. Ar. 1158; Av. Ar. 1187; Av. Ar. 1301;

Avianus, Fabulae: Monstrum (var.): Avian. Fab. 29.19;

Claudianus: Prodigium (div.): Claud. De rap. II 10; Claud. Stil. II 291; Claud. De bello Goth. 26.62; Claud. De bello Goth. 26.253; Claud. In Eutr. I 22; Claud. In Eutr. II 4; Prodigium (var.): Claud. Stil. III 346; Claud. De cons. Fl. Man. Theod. 297; Claud. In Ruf. I 89; Claud. In Eutr. I 232; Portentum (var.): Claud. Stil. II 307; Claud. De IV cons. Hon. Aug. 313; Claud. In Eutr. I 236; Claud. In Eutr. II 88; Ostentum (div.): Claud. De bello Goth. 26.249; Monstrum (div.): Claud. De bello Goth. 26.229; Claud. In Eutr. II 39; Monstrum (var.): Claud. De rap. I 37; Claud. De rap. II praef. 30; Claud. De rap. II 9; Claud. Stil. II 28; Claud. Stil. II 247; Claud. Stil. II 298; Claud. Stil. III 274; Claud. Stil. III 361; Claud. De bello Goth. 26.20; Claud. In Eutr. I 8; Claud. In Eutr. I 236; Claud. In Eutr. I 351; Claud. In Eutr. II 428; Claud. In Eutr. II 501; Claud. In Ruf. I 40; Claud. In Ruf. I 291; Claud. In Ruf. II 99; Claud. De bello Gild. 257; Claud. De bello Gild. 362; Claud. Epit. de nupt. Hon. Aug. 161; Claud. Carm. min. IV (LIV) 9; Claud. Carm. min. XXX (XXXIX) 129; 
Luxorius: Monstrum (var.): Lux. 31.1; Lux. 79.5;

Dracontius: Prodigium (div.): Drac. De laud. Dei I 42; Ostentum (div.): Drac. De laud. Dei I 85; Monstrum (div.): Drac. De laud. Dei I 63; Drac. Orest. 825; Monstrum (var.): Drac. De laud. Dei I 307; Drac. De laud. Dei III 211; Drac. Verba Herc. 17; Drac. Med. 38;

Plautus: Prodigium (div.): Pl. Bach. 1141; Monstrum (div.): Pl. As. 289; Monstrum (var.): Pl. Most. 505; Pl. Poen. 273;

Terentius: Monstrum (div.): Ter. Phorm. 705; Monstrum (var.): Ter. Phorm. 954; Ter. Andr. 250; Ter. Eun. 354; Ter. Eun. 656; Ter. Eun. 696; Ter. Eun. 860;

Seneca Minor: Prodigium (var.): Sen. Phaed. 175; Portentum (var.): Sen. Her. f. 603; Monstrum (div.): Sen. Tyest. 703; Monstrum (var.): Sen. Med. 190; Sen. Med. 472; Sen. Med. 479; Sen. Med. 675; Sen. Med. 684; Sen. Phaed. 122; Sen. Phaed. 143; Sen. Phaed. 144; Sen. Phaed. 649; Sen. Phaed. 898; Sen. Phaed. 1016; Sen. Phaed. 1034; Sen. Phaed. 1046; Sen. Phaed. 1160; Sen. Phaed. 1204; Sen. Ag. 337; Sen. Ag. 838; Sen. Ag. 997; Sen. Oed. 106; Sen. Oed. 641; Sen. Oed. 724; Sen. Oed. 743; Sen. Tyest. 12; Sen. Tyest. 254; Sen. Tyest. 632; Sen. Tyest. 673; Sen. Tyest. 867; Sen. Phoen. 122; Sen. Phoen. 137; Sen. Troad. 169; Sen. Troad. 1154; Sen. Her. f. 40; Sen. Her.f. 62; Sen. Her. f. 82; Sen. Her. f. 215; Sen. Her. f. 241; Sen. Her. f. 434; Sen. Her. f. 444; Sen. Her. f. 454; Sen. Her. f. 528; Sen. Her. f. 778; Sen. Her. f. 807; Sen. Her. f. 939; Sen. Her. f. 1020; Sen. Her. f. 1063; Sen. Her. f. 1254; Sen. Her. f. 1280;

Pseudo-Seneca: Portentum (var.): Ps.-Sen. Her. O. 74; Monstrum (var.): Ps.-Sen. Oct. 372; Ps.-Sen. Her. O. 288; Ps.-Sen. Her. O. 728; Ps.-Sen. Her. O. 878; Ps.-Sen. Her. O. 54; Ps.-Sen. Her. O. 55; Ps.-Sen. Her. O. 61;

Valerius Maximus: Prodigium (div.): Val. Max. I 1.8; Val. Max. I 6.1; Val. Max. I 6.3; Val. Max. I 6.5; Val. Max. I 6.6; Val. Max. I 6.7; Val. Max. I 6.8; Val. Max. I 6.11; Val. Max. I 6.12; Val. Max. I 6. ext. 1; Val. Max. I ext. 2; Val. Max. I 6. ext. 3; Val. Max. I 7. ext. 7; Val. Max. V 6.3; Portentum (div.): Val. Max. I 1.1; Portentum (var.): Val. Max. II 4.1; Val. Max. III 5. init.; Val. Max. III 8.6; Ostentum (div.): Val. Max. I 1.1; Val. Max. I 6. ext. 1; Monstrum (div.): Val. Max. I 6.5; Val. Max. I 6.11; Val. Max. I 6. ext. 1; Val. Max. I 7. ext. 1; Val. Max. VIII 11.1; Monstrum (var.): Val. Max. I 8. ext. 3; Val. Max. III 5.1; Val. Max. IV 3.6; Val. Max. IV 7.4; Val. Max. V 3.4; Val. Max. V 3. ext. 3; Val. Max. VIII 3.2; Val. Max. IX 11.1; Val. Max. IX 15.1;

Petronius: Portentum (var.): Petr. Sat. 47; Ostentum (div.): Petr. Sat. 122.141; Monstrum (div.): Petr. Sat. 89.29; Monstrum (var.): Petr. Sat. 111; Petr. Sat. 126;

Hyginus, Fabulae: Prodigium (div.): Hyg. Fab. 3; Hyg. Fab. 45; Hyg. Fab. 67; Monstrum (div.): Hyg. Fab. 136; Monstrum (var.): Hyg. Fab. 134; 
Apuleius: Portentum (div.): Apul. Met. III 2; Ostentum (div.): Apul. Met. IX 33;Apul. Met. IX 34; Apul. Met. IX 38; Apul. Met. X 17; Monstrum (div.): Apul. Met. X 17; Monstrum (var.): Apul. Met. III 9; Apul. Ap. 85.8; Apul. Flor. 3.7; Apul. Flor. 22.3;

Cicero: Prodigium (div.): Cic. In Verr. II 4.107; Cic. De harusp. 10; Cic. De harusp. 44; Cic. Phil. IV 10; Cic. Or. 155; Cic. De partit. 73; Cic. De inv. I 101; Cic. Rep. I 23; Cic. Leg. II 21; Cic. ND. II 7; Cic. ND. III 68; Cic. DD. I 93; Prodigium (var.): Cic. Pro Rosc. 38; Cic. In Verr. II 2.79; Cic. In Verr. II 3.171; Cic. In Verr. II 4.47; Cic. Pro Sest. 38; Cic. In Pis. 9; Cic. In. Pis. frg. 1.1; Cic. Pro Lig. 11; Cic. In Vat. 36; Cic. In tog. cand. frg. 15; Cic. In Clod. et Cur. frg. 22; Cic. De harusp. 4; Portentum (div.): Cic. De harusp. 11; Cic. De harusp. 18; Cic. Phil. IV 10; Cic. Or. 155; Cic. Top. 77; Cic. Leg. II 21; Cic. ND. II 7; Cic. ND. II 14; Cic. ND. II 163; Cic. ND. III 5; Cic. ND. III 68; Cic. DD. I 35; Cic. DD. I 39; Cic. DD. I 76; Cic. DD. I 92; Cic. DD. I 93; Cic. DD. II 59; Cic. DD. II 61; Cic. DD. II 62; Cic. DD. II 63; Cic. DD. II 64; Portentum (var.): Cic. Pro Rosc. 38; Cic. Pro Rosc. 63; Cic. In Verr. II 1.40; Cic. De leg. agr. II 55; Cic. Pro Clu. 188; Cic. Pro Sull. 76; Cic. In Pis. 9; Cic. In. Pis. frg. 1.1; Cic. Pro Mil. 63; Cic. In tog. cand. frg. 15; Cic. Phil. II 66; Cic. Phil. V 11; Cic. Phil. V 13; Cic. Phil. XIII 49; Cic. Phil. XIV 8; Cic. De dom. 47; Cic. De dom. 129; Cic. Att. XIV 21.1; Cic. Fam. X 32.3; Cic. Or. 26; Cic. Luc. 123; Cic. De fin. IV 70; Cic. Tusc. I 11; Cic. De or. II 298; Cic. Rep. III 14; Cic. ND. I 18; Cic. ND. I 43; Cic. ND. II 5; Cic. ND. III 91; Ostentum (div.): Cic. In Verr. II 4.108; Cic. De harusp. 10; Cic. De harusp. 18; Cic. De harusp. 31; Cic. De harusp. 61; Cic. De inv. I 101; Cic. ND. II 7; Cic. ND. II 166; Cic. Cic. DD. I 73; Cic. DD. I 93; Cic. DD. I 94; Cic. DD. I 99; Cic. DD. I 118; Cic. DD. I 121; Cic. DD. I 127; Cic. DD. II 16; Cic. DD. II 26; Cic. DD. II 42; Cic. DD. II 49; Cic. DD. II 53; Cic. DD. II 55; Cic. DD. II 56; Cic. DD. II 62; Cic. DD. II 66; Cic. DD. II 67; Cic. DD. II 69; Cic. DD. II 70; Cic. DD. II 109; Cic. DD. II 149; Ostentum (var.): Cic. Fam. VIII 14.4; Monstrum (div.): Cic. De harusp. 26; Cic. De partit. 73; Cic. ND. II 7; Cic. ND. III 5; Cic. DD. I 3; Cic. DD. I 12; Cic. DD. I 49; Cic. DD. I 92; Cic. DD. I 93; Cic. DD. I 97; Cic. DD. I 98; Cic. DD. I 109; Cic. DD. II 59; Cic. DD. II 64; Cic. DD. II 65; Cic. DD. II 87; Monstrum (var.): Cic. Pro Rosc. 63; Cic. In Verr. II 2.79; Cic. In Verr. II 2.158; Cic. In Verr. II 3.171; Cic. In Verr. II 4.47; Cic. In Verr. II 5.145; Cic. Pro Clu. 188; Cic. Pro Sest. 53; Cic. Pro Cael. 12; Cic. In Pis. 31; Cic. In. Pis. frg. 1.1; Cic. In tog. cand. frg. 15; Cic. Phil. XIII 49; Cic. Cat. II 1; Cic. Att. IV 7.1; Cic. Att. V 16.2; Cic. Att. IX 11.4; Cic. Att. IX 13.7; Cic. Att. X 11.4; Cic. Q. fr. II 4.5; Cic. Brut. II 2.3; Cic. Tusc. IV 54; Cic. ND. I 28; Cic. ND. III 44;

Seneca Maior: Prodigium (var.): Sen. Contr. I 7.8; Portentum (var.): Sen. Contr. I 3.4; Sen. Contr. II 6.4; Sen. Contr. X praef. 10; Sen. Suas. 1.1; Sen. Suas. 1.13; Monstrum (var.): Sen. Contr. X 3.4; Sen. Contr. X 4.3; Sen. Suas. 1.15;

Seneca Minor: Prodigium (var.): Sen. Ad Luc. V 50.2; Portentum (var.): Sen. Ad Luc. 82.24; Sen. Ad Luc. 92.10; Sen. Ad Luc. 110.12; Sen. De ira III 15.2; Sen. 
Debenef. VII 20.4; Monstrum (var.): Sen. Ad Luc. 88.7; Sen. De ira II 35.5; Sen. De ira III 3.2; Sen. De ira III 17.4; Sen. De Const. 2.2; Sen. De clem. I 25.4; Sen. Apoc. 5;

Quintilianus: Prodigium (div.): Quint. Inst. or. I 10.47; Prodigium (var.): Quint. Inst. or. VII proem. 2; Quint. Inst. or. VIII proem. 33; Monstrum (var.): Quint. Inst. or. I 1.2; Quint. Inst. or. IV 2.39; Quint. Inst. or. V 12.19; Quint. Inst. or. VIII 3.60; Quint. Inst. or. VIII 6.72;

Pseudo-Quintilianus: Prodigium (div.): Ps.-Quint. D. min. 372.4; Prodigium (var.): Ps.-Quint. D. maior. XII 3; Ps.-Quint. D. min. 319.4; Portentum (var.): Ps.-Quint. D. maior. VIII 14; Ps.-Quint. D. maior. IX 11; Monstrum (div.): Ps.-Quint. D. maior. IV 16; Ps.-Quint. D. maior. XV 8; Monstrum (var.): Ps.-Quint. D. maior. II 2; Ps.-Quint. D. maior. VI 8; Ps.-Quint. D. maior. VIII 14; Ps.-Quint. D. maior. XI 2; Ps.-Quint. D. maior. XII 8; Ps.-Quint. D. maior. XII 9; Ps.-Quint. D. maior. XII 26; Ps.-Quint. D. maior. XVIII 1; Ps.-Quint. D. maior. XVIII 11; Ps.-Quint. D. maior. XIX 13; Ps.-Quint. D. min. 299.8; Ps.-Quint. D. min. 329.5;

Plinius Minor: Prodigium (var.): Plin. Ep. IX 17.3; Monstrum (var.): Plin. Ep. VII 27.6;

Fronto: Ostentum (div.): Fr. Ad Verum Imp. II. 8;

Panegyrici Latini: Prodigium (div.): Paneg. Const. Aug. XII 14; Prodigium (var.): Paneg. Max. Aug. II 2.1; Paneg. Const. Aug. XII 7; Portentum (var.): Paneg. Const. Aug. XII 14; Monstrum (var.): Paneg. Max. Aug. II 4.3; Paneg. Geneth. Max. Aug. III 3; Paneg. Const. Aug. XII 3; Paneg. Theod. Aug. II 44;

Varro, De re rustica: Portentum (div.): Var. RR. I 1.4; Var. RR. II 1.27; Var. RR. II 4.18;

Columella: Prodigium (div.): Col. RR. VII 11.3; Prodigium (var.): Col. RR. I praef. 7; Monstrum (var.): Col. RR. X 337;

Seneca Minor, Quaestiones naturales: Prodigium (div.): Sen. QN. I 1.3; Sen. QN. II 38.3; Sen. QN. VI 26.3; Sen. QN. VII 1.5; Portentum (var.): Sen. QN. praef. 5; Sen. QN. I 16.3; Ostentum (div.): Sen. QN. II 34.1; Ostentum (var.): Sen. QN. VII 21.1; Monstrum (var.): Sen. QN. I 16.6; Sen. QN. VI 28.3;

Plinius Secundus: Prodigium (div.): Plin. HN. I 2.25-35; Plin. HN. II 137; Plin. HN. II 222; Plin. HN. I 11.76; Plin. HN. V 58; Plin. HN. VII 34; Plin. HN. VII 74; Plin. HN. VIII 55; Plin. HN. VIII 153; Plin. HN. VIII 173; Plin. HN. VIII 183; Plin. HN. VIII 206; Plin. HN. X 41; Plin. HN. XI 197; Plin. HN. XI 270; Plin. HN. XII 129; Plin. HN. XI 191; Plin. HN. XVI 132; Plin. HN. XVII 241; Plin. HN. XVII 242; Plin. HN. XVII 244; Plin. HN. XVII 245; Plin. HN. XXIX 82; Plin. HN. XXXVI 136; Prodigium (var.): Plin. HN. I 17.38; Plin. HN. I 36.70; Plin. HN. VII 32; Plin. HN. VII 179; Plin. HN. XIV 116; Plin. HN. XIV 132; Plin. HN. XIX 54; Plin. HN. XXXIII 4; Plin. HN. XXXVI 34; Plin. HN. XXXVII 29; Plin. HN. XXXVII 54; Portentum (div.): Plin. HN. I 2.58; Plin. HN. I 281-86; Plin. HN. II 199; Plin. HN. I 17.externis; Plin. HN. XXXVI 2; Portentum (var.): Plin. HN. VIII 226; Plin. HN. XI 272; Plin. HN. 
XI 262; Plin. HN. XII 12; Plin. HN. XVI 118; Plin. HN. XIX 153; Plin. HN. XXIV 18; Plin. HN. XXV 25; Plin. HN. XXVIII 30; Plin. HN. XXVIII 70; Plin. HN. XXXVII 50; Ostentum (div.): Plin. HN. II 47; Plin. HN. I.2.25-25; Plin. HN. II 144; Plin. HN. II 150; Plin. HN. II 199; Plin. HN. II 200; Plin. HN. I 28.4-5; Plin. HN. VII 33; Plin. HN. VII 34; Plin. HN. VII 203; Plin. HN. VIII 55; Plin. HN. VIII 158; Plin. HN. VIII 221; Plin. HN. VIII 223; Plin. HN. X 28; Plin. HN. X 35; Plin. HN. X 49; Plin. HN. XI 55; Plin. HN. XI 56; Plin. HN. XI 190; Plin. HN. XV 78; Plin. HN. XVI 132; Plin. HN. XVII 242; Plin. HN. XVII 243; Plin. HN. XVIII 166; Plin. HN. XXVIII 14; Plin. HN. XXVIII 17; Plin. HN. XXXVII 4; Plin. HN. XXXVII 16; Monstrum (div.): Plin. HN. VII 35; Monstrum (var.): Plin. HN. II 21; Plin. HN. II 140; Plin. HN. VII 9; Plin. $H N$. VIII 55; Plin. HN. VIII 72; Plin. HN. VIII 79; Plin. HN. IX 91; Plin. HN. IX 92; Plin. HN. IX 153; Plin. HN. X 34; Plin. HN. XIX 53; Plin. HN. XXVIII 6; Plin. HN. XXVIII 116; Plin. HN. XXIX 72; Plin. HN. XXX 13; Plin. HN. XXXVI 77;

Solinus: Ostentum (div.): Sol. I 67; Monstrum (var.): Sol. XXVII 26; Sol. XXVII 34; Sol. XXX 20; Sol. XXXII 27; Sol. XXXIV 2; Sol. XL 11; Sol. LII 39; Sol. LVI 11; Sol. LVI 19;

Censorinus: Prodigium (var.): Cens. 14.6; Portentum (div.): Cens. 17.5; Cens. 17.6; Cens. 17.8; Ostentum (div.): Cens. 17.6;

Firmicus Maternus, Mathesis: Prodigium (var.): Firm. Math. IV 12.6; Portentum (var.): Firm. Math. VII 7.2; Monstrum (var.): Firm. Math. VII 7.2;

Palladius: Prodigium (div.): Pall. De agr. XIV 38.2; Portentum (var.): Pall. De agr. I 35.3; Monstrum (var.): Pall. De agr. I 35.11; Pall. De agr. I 35.16;

Varro, De lingua latina: Prodigium (div.): Varr. LL. V 144; Monstrum (var.): Varr. LL. VII 64;

Suetonius, Pratum, verborum differentia: Prodigium (var.): Suet. Prat. s.v.; Ostentum (var.): Suet. Prat. s.v.; Monstrum (var.): Suet. Prat. s.v.;

Aulus Gellius: Prodigium (div.): Aul. Gel. NA. IX 4.16; Portentum (var.): Aul. Gel. NA. X 12.1; Aul. Gel. NA. X 12.6; Aul. Gel. NA. XV 4.3; Ostentum (div.): Aul. Gel. NA. VI 1.5; Aul. Gel. NA. XVI 6.11; Monstrum (var.): Aul. Gel. NA. II 6.1; Aul. Gel. NA. XI 7.8; Aul. Gel. NA. XII 5.13; Aul. Gel. NA. XVI 1.1; Aul. Gel. NA. XVII 10.19;

Festus: Prodigium (div.): Fest. 122; Fest. 218; Fest. 254; Fest. 254; Fest. 342; Fest. 370; Portentum (div.): Fest. 122; Fest. 236; Fest. 284; Fest. 284; Ostentum (div.): Fest. 122; Fest. 214; Fest. 218; Fest. 284; Ostentum (var.): Fest. 214; Monstrum (div.): Fest. 122; Fest. 146; Fest. 284;

Macrobius, Saturnalia: Prodigium (div.): Macr. Sat. I 6.13; Macr. Sat. I 6.23; Macr. Sat. III 20.3; Portentum (div.): Macr. Sat. III 20.3; Ostentum (div.): Macr. Sat. II 3.5; Macr. Sat. VI 9.2; Monstrum (div.): Macr. Sat. III 10.6; Macr. Sat. III 10.7; Macr. Sat. III 11.1; Monstrum (var.): Macr. Sat. I 20.14; Macr. Sat. IV 5.11; Macr. Sat. V 17.14; Macr. Sat. VI 7.4; 
Servius, In Vergilii Aeneidem commentarii: Prodigium (div.): Serv. Aen. II 202; Serv. Aen. II 681; Serv. Aen. III pr.; Serv. Aen. III 21; Serv. Aen. III 231; Serv. Aen. III 366; Serv. Aen. IV 377; Serv. Aen. V 639; Serv. Aen. VI 379; Prodigium (var.): Serv. Aen. III 241; Serv. Aen. VIII 294; Portentum (div.): Serv. Aen. III 366; Serv. Aen. VII 58; Serv. Aen. VIII 533; Portentum (var.): Serv. Aen. VI 289; Serv. Aen. XI 271; Ostentum (div.): Serv. Aen. III 5; Serv. Aen. III 366; Serv. Aen. IX 20; Monstrum (div.): Serv. Aen. I 444; Serv. Aen. II 172; Serv. Aen. III 26; Serv. Aen. III 39; Serv. Aen. III 59; Serv. Aen. III 265; Serv. Aen. III 307; Serv. Aen. III 366; Serv. Aen. V 523; Serv. Aen. V 849; Serv. Aen. VII 269; Serv. Aen. VIII 81; Serv. Aen. IX 126; Serv. Aen. XII 246; Serv. Aen. XII 874; Monstrum (var.): Serv. Aen. I 3; Serv. Aen. I 201; Serv. Aen. I 330; Serv. Aen. I 741; Serv. Aen. II 230; Serv. Aen. II 245; Serv. Aen. II 681; Serv. Aen. III 3; Serv. Aen. III 74; Serv. Aen. III 420; Serv. Aen. III 431; Serv. Aen. IV 181; Serv. Aen. V 118; Serv. Aen. VI 286; Serv. Aen. VII 732; Serv. Aen. VIII 198; Serv. Aen. VIII 200; Serv. Aen. VIII 288; Serv. Aen. VIII 289; Serv. Aen. VIII 698;

Probus, Appendix Probi: Prodigium (div.): Gram. Lat. IV. 200; Portentum (div.): Gram. Lat. IV. 200; Ostentum (div.): Gram. Lat. IV. 200; Monstrum (div.): Gram. Lat. IV. 200;

Martianus Capella: Prodigium (div.): Mart. Cap. II 151;

Nonius Marcellus: Prodigium (div.): Non. 23; Non. 64; Non. 365; Non. 694; Non. 701; Portentum (div.): Non. 272; Non. 598; Non. 694; Non. 701-702; Portentum (var.): Non. 281; Non. 855; Ostentum (div.): Non. 693; Monstrum (div.): Non. 75; Non. 499; Non. 554; Non. 554; Non. 583; Non. 664; Non. 693; Non. 701; Non. 752; Non. 839;

De proprietate sermonum: Prodigium (div.): PSR 217; Ostentum (div.): PSR 217; Monstrum (div.): PSR 217;

Isidorus Hispalensis, Etymologiae: Prodigium (div.): Isid. Etym. XI 3.2; Isid. Etym. XI 3.3; Prodigium (var.): Isid. Etym. VII 9.1; Portentum (div.): Isid. Etym. XI 3.3; Isid. Etym. XI 3.4; Portentum (var.): Isid. Etym. XI 3; Isid. Etym. XI 3.1; Isid. Etym. XI 3.2; Isid. Etym. XI 3.6; Isid. Etym. XI 3.7; Isid. Etym. XI 3.9; Isid. Etym. XI 3.10; Isid. Etym. XI 3.28; Isid. Etym. XVIII 34.2; Ostentum (div.): Isid. Etym. XI 3.2; Isid. Etym. XI 3.3; Monstrum (div.): Isid. Etym. XI 3.2; Isid. Etym. XI 3.3; Isid. Etym. XI 3.5; Isid. Etym. XI 3.5; Monstrum (var.): Isid. Etym. XI 3.12; Isid. Etym. XI 3.33; Isid. Etym. XIII 18.3; Isid. Etym. XIV 3.7; Isid. Etym. VIII 11.37;

Isidorus, De differentiis verborum: Prodigium (div.): Isid. De diff. I 459; Portentum (div.): Isid. De diff. I 458; Isid. De diff. I 459; Portentum (var.): Isid. De diff. I 457; Ostentum (div.): Isid. De diff. I 459; Monstrum (div.): Isid. De diff. I 459; Monstrum (var.): Isid. De diff. I 457;

Anonymus, De differentiis: Prodigium (var.): Anon. De diff. 520.20-27; Portentum (div.): Anon. De diff. 520.20-27; Ostentum (var.): Anon. De diff. 520.20-27; Monstrum (var.): Anon. De diff. 520.20-27; 
Paulus, Excerpta: Prodigium (div.): Fest. Paul. 125; Fest. Paul. 250; Fest. Paul. 255; Portentum (div.): Fest. Paul. 125; Portentum (var.): Fest. Paul. 285; Ostentum (div.): Fest. Paul. 125; Fest. Paul. 215; Monstrum (div.): Fest. Paul. 125; Monstrum (var.): Fest. Paul. 147;

Codex Iustiniani: Prodigium (var.): CF. 6.29.3.1; Monstrum (var.): CF. 6.29.3.1;

Digesta: Ostentum (div.): Dig. 50.16.38;

Minucius Felix: Portentum (var.): Min. Fel. Oct. 10.5; Min. Fel. Oct. 25.9; Monstrum (var.): Min. Fel. Oct. 10.5; Min. Fel. Oct. 23.7; Min. Fel. Oct. 28.2;

Tertullianus: Prodigium (div.): Tert. Adv. Mar. IV 39.3; Tert. Adv. Mar. IV 39.9; Prodigium (var.): Tert. Ad nat. II 7; Tert. De pall. 4.1; Portentum(div.): Tert. Ad scap. 3.3.; Tert. Apol. 20.3; Portentum (var.): Tert. De res. car. 22.2; Tert. De res. car. 24.2; Tert. De spect. 9.3; Ostentum (var.): Tert. Adv. Mar. V 16.4; Tert. De anim. 51.8; Tert. Scorp. 2.8; Monstrum (div.): Tert. Apol. 20.3; Monstrum (var.): Tert. Apol. 14.3; Tert. Cor. Mil. 5.4; Tert. Idol. 3.1; Tert. De ieiun. 1.1; Tert. De pall. 4.2; Tert. De pall. 4.2; Tert. De pall. 4.3; Tert. De pudic. 4.5; Tert. De virg. 9.5;

Arnobius: Prodigium (var.): Arn. Ad. nat. I 11.3; Arn. Ad. nat. IV 27.2; Arn. Ad. nat. IV 34.2; Arn. Ad. nat. VII 36.4; Portentum (div.): Arn. Ad. nat. VI 2.1; Monstrum (var.): Arn. Ad. nat. III 10.5; Arn. Ad. nat. IV 11.2; Arn. Ad. nat. V 30.1; Arn. Ad. nat. VII 36.4;

Firmicus Maternus, De errore: Prodigium (var.): Firm. De err. 4.2; Monstrum (var.): Firm. De err. 4.2;

Augustinus, De civitate Dei: Prodigium (div.): Aug. CD. III 11; Aug. CD. III 31; Aug. CD. III 31; Aug. CD. X 17; Aug. CD. XVIII 9; Aug. CD. XVIII 10; Aug. CD. XXI 8; Prodigium (var.): Aug. CD. XII 28; Aug. CD. XX 19; Aug. CD. XXI 6; Aug. CD. XXI 8; Portentum (div.): Aug. CD. XXI 8; Ostentum (div.): Aug. CD. XXI 8; Ostentum (var.): Aug. CD. XVIII 50; Monstrum (div.): Aug. CD. XXI 8; Monstrum (var.): Aug. CD. VI 10; Aug. CD. VII 26; Aug. CD. XII 14; Aug. CD. XVI 8; Aug. CD. XVIII 13; Aug. CD. XIX 12.

Dominika Lewandowska ORCID: 0000-0003-4761-7932 Faculty of Oriental Studies, Faculty of History University of Warsaw dominika.lewandowska@uw.edu.pl 
Prodigium, PORTENTUM, OSTENTUM, MONSTRUM: W POSZUKIWANIU ZNACZENIA MiĘDZY PRAKTYKĄ A DEFINICJĄ

\begin{abstract}
Abstrakt
Artykuł poświęcony jest analizie wystąpień w źródłach czterech pojęć: prodigium, portentum, ostentum, monstrum oraz skonfrontowaniu wyników z antycznymi definicjami tychże określeń. W pierwszej części zebrano łącznie 1489 poświadczeń i przeanalizowano ich wystąpienia według kontekstu „dywinacyjnego” i „innego” oraz względem kategorii źródeł: „historiografia”, „poezja”, „dramat”, „proza”, „filozofia i retoryka”, „teksty specjalistyczne”, „teksty gramatyczne”, „teksty prawne” oraz wybrane „teksty wczesnochrześcijańskie”. W drugiej części skupiono się na analizie definicji omawianych pojęć, które podzielono na: „etymologiczne”, „wskazujące na desygnat”, „wskazujące na konotację”, „hybryowe”. Wykazano, że tylko połowa badanych pojęć należy do kontekstu „dywinacyjnego”; można zaobserwować wyraźną preferencję do korzystania z określonych pojęć przy wzięciu pod uwagę kategorię źródeł; najbardziej jednolite znaczeniowo jest ostentum, a największą dysproporcję między znaczeniem „dywinacyjnym” a „innym” (na korzyść tego drugiego) wykazuje monstrum.
\end{abstract}

Słowa kluczowe: prodigium, portentum, ostentum, monstrum, omen, Festus, definicja, dywinacja

Prodigium, portentum, ostentum, monstrum: in SEARCH of MEANing BetWeen PRACTICE AND DEFINITION

\begin{abstract}
The article is focused on analysing the occurrences of four terms used in the sources: prodigium, portentum, ostentum, monstrum, and confronting the results with ancient definitions of these terms. In the first part, a total of 1,489 attestations were collected and their occurrences were analysed according to 'divinatory' and 'various' contexts and in relation to source categories: 'Historiography', 'Poetry', 'Drama', 'Prose', 'Philosophy \& Rhetoric', 'Technical', 'Grammatical', 'Legal', and selected 'Early Christian'. The second part focuses on analysing the definitions of the terms in question, which are divided into: 'Etymological definitions', 'Indicating
\end{abstract}


referent (denotation)', 'Indicating connotation', and 'Hybrid'. It has been shown that only half of the studied terms belong to the 'divinatory' context; a clear preference can be observed for the use of specific terms when taking into account the category of sources; ostentum is the most homogenous in meaning, and the greatest disproportion between 'divinatory' and 'various' meaning (in favour of the latter) shows monstrum.

Keywords: prodigium, portentum, ostentum, monstrum, omen, Festus, definition, divination 